\title{
Characterization of the Aminosugar Biosynthetic and Regulatory Genes of \\ Vicenistatin in Monodonata labio-associated Streptomyces parvus SCSIO Mla-
}

\section{L010}

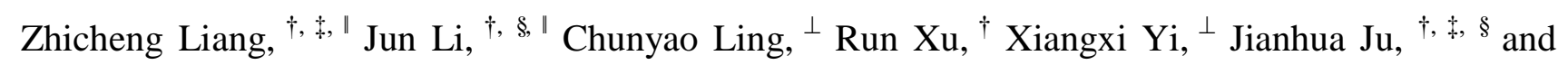
Qinglian $\mathrm{Li}^{\dagger}, \S, *$

${ }^{\dagger}$ CAS Key Laboratory of Tropical Marine Bio-resources and Ecology, Guangdong Key Laboratory of Marine Materia Medica, RNAM Center for Marine Microbiology, South China Sea Institute of Oceanology, Chinese Academy of Sciences, 164 West Xingang Road, Guangzhou 510301, China.

${ }^{\ddagger}$ College of Oceanology, University of Chinese Academy of Sciences, 19 Yuquan Road, Beijing 110039, China.

${ }^{\S}$ Southern Marine Science and Engineering Guangdong Laboratory (Guangzhou), No.1119, Haibin Rd., Nansha District, Guangzhou 511458, China.

${ }^{\perp}$ Institute of Marine Drug, School of Pharmacy, Guangxi University of Traditional Chinese Medicine, No.13 Wuhe Avenue, Qingxiu District, Nanning 530200, China.

"Z.L. and J.L. contributed equally to this research.

*To whom correspondence should be addressed.

Tel./Fax: +86-020-34066449; E-mail: $\underline{\text { liql@ } @ \text { scsio.ac.cn }}$ 
Table S1. Deduced functions of ORFs of vicenistatin gene cluster in $1-2$

Streptomyces parvus SCSIO Mla-L010.

$\begin{array}{ll}\text { Table S2. Bacteria used in this study. } & 3\end{array}$

Table S3. Plasmids used in this study. 4

Table S4. Primers used in this study. $5-6$

Table S5. ${ }^{1} \mathrm{H}$ and ${ }^{13} \mathrm{C}$ NMR data for vicenistatin (1) and 4 '-N-demethyl- 7-8 vicenistatin (2) in pyridine- $d_{5}$.

Table S6-S8. Yields of vicenistatin for WT producer, $\Delta v i c R 1:: v i c R 1$ and Mla- 9 L010::vicRl, and yields of 4'- $N$-demethyl-vicenistatinin for $\Delta v i c G$ and $\Delta v i c G:: v i c R l$.

Figure S1-S7. Disruptions of vincenistatin biosynthetic genes in wild-type $S . \quad 10-13$ parvus SCSIO Mla-L010 via PCR-targeting.

Figure S8. SDS-PAGE analysis of purified His ${ }_{6}$-tagged VicG. 14

Figure S9. HPLC analyses of the enzymatic assays of VicG. 15

Figure S10. LC-MS analysis of the fermentation extract of WT producer. 16

Figures S11. The quantitative HPLC standard curve for vicenistatin (1) 17

Figures S12. The quantitative HPLC standard curve for 4'-N-demethyl- 17 vicenistatin (2)

$\begin{array}{ll}\text { Figures S13. The (+) HRESIMS spectrum of } \mathbf{1 .} & 18\end{array}$

Figures S14-S19. 1D and 2D NMR spectra of 1 in pyridine- $d_{5}$. 19-24

Figures S20. The (+) HRESIMS spectrum of 2 . 25

Figures S21-S26. 1D and 2D NMR spectra of 2 in pyridine- $d_{5}$ 26-31

$\begin{array}{ll}\text { References } & 32\end{array}$ 
Table S1. Deduced functions of ORFs of vicenistatin gene cluster in Streptomyces parvus SCSIO Mla-L010.

\begin{tabular}{|c|c|c|c|c|}
\hline ORFs & Size(aa) & Proposed function & $\mathrm{ID} / \mathrm{SI}$ & Protein homologue \\
\hline VicR1 & 932 & $\begin{array}{l}\text { LuxR family transcriptional } \\
\text { regulator }\end{array}$ & $40 / 56$ & $\begin{array}{l}\text { SceP (ANH11411.1); } \\
\text { Streptomyces sp. SD85 }\end{array}$ \\
\hline VicA & 355 & dTDP-glucose synthase & $88 / 92$ & $\begin{array}{l}\text { VinA (BAD08355.1); } \\
\text { Streptomyces halstedii }\end{array}$ \\
\hline VicB & 322 & dTDP-glucose 4,6-dehydratase & $90 / 94$ & $\begin{array}{l}\text { VinB (BAD08356.1); } \\
\text { Streptomyces halstedii }\end{array}$ \\
\hline VicC & 419 & glycosyltransferase & $77 / 88$ & $\begin{array}{l}\text { VinC (BAD08357.1); } \\
\text { Streptomyces halstedii }\end{array}$ \\
\hline VicP2 & 2265 & polyketide synthase modules 4 & $75 / 81$ & $\begin{array}{l}\text { VinP2 (BAD08358.1); } \\
\text { Streptomyces halstedii }\end{array}$ \\
\hline VicP3 & 3415 & polyketide synthase modules 5-6 & $76 / 83$ & $\begin{array}{l}\text { VinP3 (BAD08359.1); } \\
\text { Streptomyces halstedii }\end{array}$ \\
\hline VicP4 & 3897 & polyketide synthase modules 7-8 & $75 / 81$ & $\begin{array}{l}\text { VinP4 (BAD08360.1); } \\
\text { Streptomyces halstedii }\end{array}$ \\
\hline VicG & 236 & $\mathrm{~N}$-methyltransferase & $77 / 85$ & $\begin{array}{l}\text { VinG (BAD08361.1); } \\
\text { Streptomyces halstedii }\end{array}$ \\
\hline VicF & 385 & aminotransferase & $88 / 93$ & $\begin{array}{l}\text { VinF (BAD08362.1); } \\
\text { Streptomyces halstedii }\end{array}$ \\
\hline VicD & 498 & $\begin{array}{l}\text { dTDP-4-keto-6-deoxyglucose 2,3- } \\
\text { dehydratase }\end{array}$ & $82 / 89$ & $\begin{array}{l}\text { VinD (BAD08363.1); } \\
\text { Streptomyces halstedii }\end{array}$ \\
\hline VicE & 328 & $\begin{array}{l}\text { dTDP-4-keto-6-deoxyhexose 2,3- } \\
\text { reductase }\end{array}$ & $88 / 93$ & $\begin{array}{l}\text { VinE (BAD08364.1); } \\
\text { Streptomyces halstedii }\end{array}$ \\
\hline $\mathrm{VicH}$ & 167 & glutamate mutase S-chain & $75 / 83$ & $\begin{array}{l}\text { VinH (BAD08365.1); } \\
\text { Streptomyces halstedii }\end{array}$ \\
\hline VicI & 442 & glutamate mutase E-chain & $76 / 82$ & $\begin{array}{l}\text { VinI (BAD08366.1); } \\
\text { Streptomyces halstedii }\end{array}$ \\
\hline VicJ & 299 & amidohydrolase & $88 / 92$ & $\begin{array}{l}\text { VinJ (BAD08367.1); } \\
\text { Streptomyces halstedii }\end{array}$ \\
\hline VicK & 322 & acyltransferase & $87 / 92$ & $\begin{array}{l}\text { VinK (BAD08368.1); } \\
\text { Streptomyces halstedii }\end{array}$ \\
\hline VicL & 82 & acylcarrierprotein & $79 / 88$ & $\begin{array}{l}\text { VinL (BAD08369.1); } \\
\text { Streptomyces halstedii }\end{array}$ \\
\hline VicM & 519 & adenylation enzyme/ & $82 / 86$ & VinM (BAD08370.1); \\
\hline
\end{tabular}


ATP-dependent ligase

VicN $516 \quad$ adenylation enzyme

VicO $\quad 410$

decarboxylase/ epimerase

polyketide synthase modules 1-3
Streptomyces halstedii

87/93 VinN (BAD08371.1);

Streptomyces halstedii

82/88 VinO (BAD08372.1);

Streptomyces halstedii

75/82 VinP1 (BAD08373.1);

Streptomyces halstedii

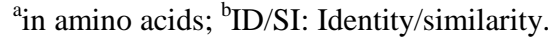


Table S2. Bacteria used in this study.

Source/

Strains

\section{Streptomycetes}

Streptomyces

parvus

SCSIO Mla- Wild-type producer of vicenistatin (1)

This work

L010

$\Delta v i c M$

S. parvus SCSIO Mla-L010 with a 1122 bp fragment of vicM substituted by a aac(3)IV+oriT cassette

This work

$\Delta v i c C$

S. parvus SCSIO Mla-L010 with a 1062 bp fragment of vicC substituted by aac(3)IV+oriT cassette

This work

$\Delta v i c D$

S. parvus SCSIO Mla-L010 with a 1059 bp fragment of vicD substituted by aac(3)IV+oriT cassette

This work

$\Delta v i c E$

S. parvus SCSIO Mla-L010 with a 789 bp fragment of vicE substituted by aac(3)IV+oriT cassette

This work

$\Delta v i c F$

S. parvus SCSIO Mla-L010 with a 960 bp fragment of $v i c F$ substituted by aac(3)IV+oriT cassette

This work

$\Delta v i c G$

S. parvus SCSIO Mla-L010 with a 513 bp fragment of vic $G$ substituted by aac(3)IV+oriT cassette

This work

$\Delta v i c R 1$

S. parvus SCSIO Mla-L010 with a 2481 bp fragment of vicRl substituted by aac(3)IV+oriT cassette

This work

Mla-

L010::vicR1

Wild-type producer strain SCSIO Mla-L010 with vicR1 overexpressed.

This work

$\Delta v i c G:: v i c R l$

$\Delta v i c G$ mutant strain with vicRl overexpressed

This work

E. coli

DH5 $\alpha \quad$ Host strain for general clone

BW25113/pIJ K-12 derivative: $\operatorname{araBAD}$, rhaBAD; host strain for Red/ET-mediated recombination
790

ET12567/pU

Z8002

$d a m, d c m, h s d M, h s d S, h s d R, c a t^{\mathrm{R}}, t^{\mathrm{R}}{ }^{\mathrm{R}}$; donor strain for conjugation between E.coli and Streptomyces 
Table S3. Plasmids used in this study.

Source/

Plasmids

Description

[Ref.]

\section{Plasmids}

pIJ773 aac(3)IV (AprR), oriT; used for amplifying the aac(3)IV-oriT gene cassette for gene inactivation

pL646 Derived from pSET152, containing ermE*P promoter and the ribosome-binding site of the tufl gene, used for overexpression of vicRl gene

SuperCos1

Used for construction of genomic cosmid library

Stratagene

cosmid 1-F11 A cosmid which contains partial abm biosynthetic cluster

This work

cosmid 13-D3 A cosmid which contains partial abm biosynthetic cluster

This work

$\mathrm{p} \Delta v i c M$

A 1122 bp fragment in vicM in cosmid 1-F11 was substituted by the aac(IV)+oriT cassette

This work

$\mathrm{p} \Delta$ vic $C$

A 1062 bp fragment in vic C in cosmid 13-D3 was substituted by the aac(IV)+oriT cassette

This work

$\mathrm{p} \Delta$ vicD A $1059 \mathrm{bp}$ fragment in vicD in cosmid 1-F11 was substituted by the aac(IV)+oriT cassette

This work

$\mathrm{p} \Delta$ vicE

A 789 bp fragment in vicE in cosmid 1-F11 was substituted by the aac(IV)+oriT cassette

This work

$\mathrm{p} \Delta v i c F$

A 960 bp fragment in vicF in cosmid 1-F11 was substituted by the aac(IV)+oriT cassette

This work

$\mathrm{p} \Delta$ vic $G$

This work

$\mathrm{p} \Delta v i c R 1$

This work 
Table S4. Primers used in this study.

\begin{tabular}{|c|c|c|}
\hline Name & Sequence (5'-3') & Purpose \\
\hline vic-upstream-tF & CGCTTCGTCCACATCTCCAC & \multirow{2}{*}{$\begin{array}{l}\text { For screening the } S \text {. } \\
\text { parvus SCSIO Mla- } \\
\text { L010 genomic library }\end{array}$} \\
\hline vic-upstream-tR & ACTTCGTCGGTTCCCACCAC & \\
\hline vic-midstream-tF & GACACCTACCGTCTGCACATTG & \multirow{2}{*}{$\begin{array}{l}\text { For screening the } S \text {. } \\
\text { parvus SCSIO Mla- } \\
\text { L010 genomic library }\end{array}$} \\
\hline vic-midstream-tR & GTCACTCAGCCAGGTCTGCAC & \\
\hline vic-downstream-tF & TCGCTCTTCCAGCTGGAGTG & \multirow{2}{*}{$\begin{array}{l}\text { For screening the } S \text {. } \\
\text { parvus SCSIO Mla- } \\
\text { L010 genomic library }\end{array}$} \\
\hline vic-downstream-tR & GGTGTCGACGAGCAGAAAGC & \\
\hline vicR1-del-F & $\begin{array}{l}\text { GACGGTGATGTAGAGCTGGCGTCCGATCTCCCGGTTGGTATTCCGGG } \\
\text { GATCCGTCGACC }\end{array}$ & \multirow[t]{2}{*}{ For disrupting vicRl } \\
\hline vicR1-del-R & $\begin{array}{l}\text { CTTCTGGAGGTGCTGTCACAGCAGGCCGTGGACTCAGGGTGTAGGC } \\
\text { TGGAGCTGCTTC }\end{array}$ & \\
\hline vicC-del-F & $\begin{array}{l}\text { GCCTGGGCCCTCACCACCGCCGGGCACGAGGTCCGCATCATTCCGG } \\
\text { GGATCCGTCGACC }\end{array}$ & \multirow[t]{2}{*}{ For disrupting vicC } \\
\hline vicC-del-R & $\begin{array}{l}\text { GGGCAGGGCCAGGTACTCCTTCTGGATCTCGTCGGCGGCTGTAGGCT } \\
\text { GGAGCTGCTTC }\end{array}$ & \\
\hline vicD-del-F & $\begin{array}{l}\text { GCCCGCGTCCGCAAGGTGCCGCTCGACGAGCTGGACGGCATTCCGG } \\
\text { GGATCCGTCGACC }\end{array}$ & \multirow[t]{2}{*}{ For disrupting vicD 3} \\
\hline vicD-del-R & $\begin{array}{l}\text { CTGGGCGTGGTAGAAGCGGCCGCCCTCCTCGGAGAGGATTGTAGGC } \\
\text { TGGAGCTGCTTC }\end{array}$ & \\
\hline vicE-del-F & $\begin{array}{l}\text { CTCAACCTCGGCGTCCGCACCACGCGCGACGAGGCGTTCACTAGTAT } \\
\text { TCCGGGGATCCGTCGACC }\end{array}$ & \multirow[t]{2}{*}{ For disrupting vicE 2} \\
\hline vicE-del-R & $\begin{array}{l}\text { GAGCCGCCCGAGGACGTCGTCGGGGAGCCGCAGGTCCAGACTAGTT } \\
\text { GTAGGCTGGAGCTGCTTC }\end{array}$ & \\
\hline vicF-del-F & $\begin{array}{l}\text { CGCGCGCGCCTGATGGAGAGACTGGACGGAGCGCTCGACATTCCGG } \\
\text { GGATCCGTCGACC }\end{array}$ & \multirow[t]{2}{*}{ For disrupting vicF } \\
\hline vicF-del-R & $\begin{array}{l}\text { CTCCGACGGCCCGACGGAGCTTCCCGTCGGGAGGGCGAGTGTAGGC } \\
\text { TGGAGCTGCTTC }\end{array}$ & \\
\hline vicG-del-F & $\begin{array}{l}\text { GCGGGGGAGGCCGACCGCATCCGCGAACTGGCCCTCGAAATTCCGG } \\
\text { GGATCCGTCGACC }\end{array}$ & \multirow[t]{2}{*}{ For disrupting vicG } \\
\hline vicG-del-R & $\begin{array}{l}\text { CACCGCGCACCCGGCCGACCGGAACGCCGCCTCGTACTCTGTAGGC } \\
\text { TGGAGCTGCTTC }\end{array}$ & \\
\hline vicM-del-F & $\begin{array}{l}\text { GTGCTCGCGGCCAAGGGAATCCCCGCCTACCAGGGCATCACTAGTA } \\
\text { TTCCGGGGATCCGTCGACC }\end{array}$ & \multirow[t]{2}{*}{ For disrupting vicM } \\
\hline vicM-del-R & $\begin{array}{l}\text { GAAGACGACGAGTTCGATGCCGGCCGCGGTGGTCGCGCCACTAGTT } \\
\text { GTAGGCTGGAGCTGCTTC }\end{array}$ & \\
\hline vicR1-tF & CTGACGTTGAGCTTGCGGTACAC & \multirow{2}{*}{$\begin{array}{l}\text { For verifying the } \\
\text { disruption of vicRl }\end{array}$} \\
\hline vicR1-tR & GTGGAGCGTGACGAAGAACTACAC & \\
\hline vicC-tF & CGTGGTGGGAACCGACGAAGTAC & \multirow{2}{*}{$\begin{array}{l}\text { For verifying the } \\
\text { disruption of vicC }\end{array}$} \\
\hline vicC-tR & CCTGTTGAAGGGCGGTCCGAAC & \\
\hline vicD-tF & GGGAGTTCCGTGGCGTCTTC & \multirow[t]{2}{*}{$\begin{array}{l}\text { For verifying the } \\
\text { disruption of vicD }\end{array}$} \\
\hline vicD-tR & TCGCTCATCGGGTTGCAGAC & \\
\hline
\end{tabular}




\begin{tabular}{|l|l|l|}
\hline vicE-tF & CTCCGGCACAGCCACTACATC & $\begin{array}{l}\text { For verifying the } \\
\text { disruption of vicE }\end{array}$ \\
\hline vicE-tR & CATGCTCCGAGGGGAAGGTG & For verifying the \\
disruption of vicF
\end{tabular}


Table S5. ${ }^{1} \mathrm{H}(700 \mathrm{MHz})$ and ${ }^{13} \mathrm{C}(176 \mathrm{MHz}) \mathrm{NMR}$ data for vicenistatin (1) and 4'- $N$ demethyl-vicenistatin (2) in pyridine- $d_{5}$.

\begin{tabular}{|c|c|c|c|c|}
\hline \multirow[t]{2}{*}{ position } & \multicolumn{2}{|r|}{ vicenistatin (1) } & \multicolumn{2}{|c|}{ 4'-N-demethyl-vicenistatin (2) } \\
\hline & $\delta_{\mathrm{C}}$, type & $\delta_{\mathrm{H}}$ mult. $(J$ in $\mathrm{Hz})$ & $\delta_{\mathrm{C}}$, type & $\delta_{\mathrm{H}}$ mult. $(J$ in $\mathrm{Hz})$ \\
\hline 1 & 166.7 & & 166.8 & \\
\hline 2 & 125.0 & $6.27,1 \mathrm{H}$ & 125.0 & $6.29,1 \mathrm{H}$ \\
\hline 3 & 140.7 & $7.62,1 \mathrm{H}$ & 140.8 & $7.63,1 \mathrm{H}$ \\
\hline 4 & 128.9 & $6.23,1 \mathrm{H}$ & 128.9 & $6.22,1 \mathrm{H}$ \\
\hline 5 & 143.8 & $5.88,1 \mathrm{H}$ & 143.82 & $5.88,1 \mathrm{H}$ \\
\hline 6 & 46.8 & 2.41 (overlapped), $1 \mathrm{H}$ & 46.9 & 2.42, overlapped, $1 \mathrm{H}$ \\
\hline 7 & 86.5 & $3.39,1 \mathrm{H}$ & 86.5 & $3.40,1 \mathrm{H}$ \\
\hline 8 & 37.0 & 2.30 (overlapped), $3.10,2 \mathrm{H}$ & 37.1 & $2.29,3.10,2 \mathrm{H}$ \\
\hline 9 & 122.4 & $5.22,1 \mathrm{H}$ & 122.5 & 5.22, overlapped, $1 \mathrm{H}$ \\
\hline 10 & 135.5 & & 135.5 & \\
\hline 11 & 49.7 & $2.64,2.76,2 \mathrm{H}$ & 49.7 & $2.65,2.76,2 \mathrm{H}$ \\
\hline 12 & 134.5 & & 134.5 & \\
\hline 13 & 128.5 & $5.98,1 \mathrm{H}$ & 128.6 & $5.98,1 \mathrm{H}$ \\
\hline 14 & 128.9 & $6.82,1 \mathrm{H}$ & 128.9 & $6.82,1 \mathrm{H}$ \\
\hline 15 & 133.0 & $5.71,1 \mathrm{H}$ & 133.0 & $5.71,1 \mathrm{H}$ \\
\hline 16 & 28.0 & $2.10,2.41$ (overlapped), $2 \mathrm{H}$ & 28.1 & $2.09,2.42$ (overlapped), $2 \mathrm{H}$ \\
\hline 17 & 33.1 & 1.49 (overlapped), $1.59,2 \mathrm{H}$ & 33.2 & $1.48,1.58,2 \mathrm{H}$ \\
\hline 18 & 34.0 & 1.86 (overlapped), $1 \mathrm{H}$ & 34.0 & $1.88,1 \mathrm{H}$ \\
\hline 19 & 43.5 & $3.05,4.05$ (overlapped), $2 \mathrm{H}$ & 43.5 & $3.05,4.05,2 \mathrm{H}$ \\
\hline $19-\mathrm{NH}$ & & $8.49,1 \mathrm{H}$ & & $8.52,1 \mathrm{H}$ \\
\hline 20 & 19.2 & $1.09,3 \mathrm{H}$ & 19.2 & $1.10,3 \mathrm{H}$ \\
\hline 21 & 18.4 & $1.71,3 \mathrm{H}$ & 18.4 & $1.72,3 \mathrm{H}$ \\
\hline 22 & 17.9 & $1.97,3 \mathrm{H}$ & 17.9 & 1.97. $3 \mathrm{H}$ \\
\hline 23 & 18.1 & $0.86,3 \mathrm{H}$ & 18.1 & $0.86,3 \mathrm{H}$ \\
\hline $1^{\prime}$ & 100.2 & $5.31,1 \mathrm{H}$ & 100.4 & $5.36,1 \mathrm{H}$ \\
\hline $2^{\prime}$ & 39.9 & a 2.41 (overlapped), $1 \mathrm{H}$ & 40.9 & a 2.42(overlapped), $1 \mathrm{H}$ \\
\hline & & b 1.86 (overlapped), $1 \mathrm{H}$ & & b $2.00,1 \mathrm{H}$ \\
\hline $3^{\prime}$ & 63.6 & $4.43,1 \mathrm{H}$ & 69.1 & $4.35,1 \mathrm{H}$ \\
\hline
\end{tabular}




\begin{tabular}{r|ll||ll}
\hline $4^{\prime}$ & 65.5 & 2.30 (overlapped), $1 \mathrm{H}$ & 57.9 & $2.68,1 \mathrm{H}$ \\
$5^{\prime}$ & 70.8 & 4.05 (overlapped), $1 \mathrm{H}$ & 72.1 & $4.10,1 \mathrm{H}$ \\
$6^{\prime}$ & 20.0 & $1.55,3 \mathrm{H}$ & 19.7 & $1.52,3 \mathrm{H}$ \\
$7^{\prime}$ & 34.3 & $2.47,3 \mathrm{H}$ & & \\
\hline
\end{tabular}


Table S6. Yields of vicenistatin for WT producer and $\Delta v i c R 1: \because v i c R 1$ based on the calibration curve from Figure S11.

\begin{tabular}{|c|c|c|c|c|c|c|c|c|}
\hline Strains & \multicolumn{4}{|c|}{ WT producer } & \multicolumn{4}{|c|}{$\Delta v i c R 1:: v i c R 1$} \\
\hline \multirow{2}{*}{$\begin{array}{l}\text { Vicenistation } \\
(\mathrm{mg} / \mathrm{L})\end{array}$} & Repeat 1 & Repeat 2 & Repeat 3 & $\begin{array}{l}\text { Mean } \\
\pm \text { SD }\end{array}$ & Repeat 1 & Repeat 2 & Repeat 3 & $\begin{array}{l}\text { Mean } \\
\pm \mathrm{SD}\end{array}$ \\
\hline & 12.23 & 10.12 & 12.91 & $\begin{array}{l}11.75 \\
\pm 1.45\end{array}$ & 62.74 & 53.97 & 58.23 & $\begin{array}{l}58.31 \\
\pm 4.38\end{array}$ \\
\hline
\end{tabular}

Table S7. Yield of vicenistatin for Mla-L010::vicR1 based on the calibration curve from Figure S11.

\begin{tabular}{l|lccc}
\hline Strain & \multicolumn{4}{|c}{ Mla-L010::vicR1 } \\
\hline Vicenistation & Repeat 1 & Repeat 2 & Repeat 3 & Mean \pm SD \\
$(\mathrm{mg} / \mathrm{L})$ & & & & $48.15 \pm 6.92$ \\
\cline { 2 - 5 } & 56.13 & 44.61 & 43.71 & \\
\hline
\end{tabular}

Table S8. Yields of 4'-N-demethyl-vicenistatin for $\Delta v i c G$ and $\Delta v i c G: \because v i c R l$ based on the calibration curve from Figure S12.

\begin{tabular}{|c|c|c|c|c|c|c|c|c|}
\hline Strains & \multicolumn{4}{|c|}{$\Delta v i c G$} & \multicolumn{4}{|c|}{$\Delta v i c G: \because v i c R 1$} \\
\hline & Repeat 1 & Repeat 2 & Repeat 3 & $\begin{array}{l}\text { Mean } \\
\pm \text { SD }\end{array}$ & Repeat 1 & Repeat 2 & Repeat 3 & $\begin{array}{l}\text { Mean } \\
\pm \text { SD }\end{array}$ \\
\hline$(\mathrm{mg} / \mathrm{L})$ & 2.90 & 3.17 & 5.96 & $\begin{array}{l}4.01 \pm \\
1.70\end{array}$ & 11.31 & 9.54 & 15.63 & $\begin{array}{l}12.15 \\
\pm 3.13\end{array}$ \\
\hline
\end{tabular}


A

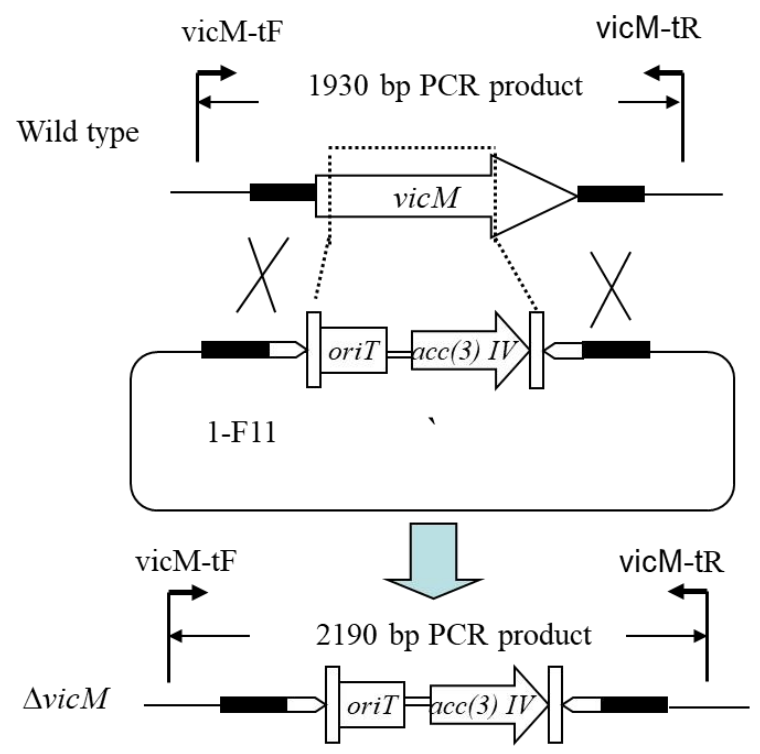

B

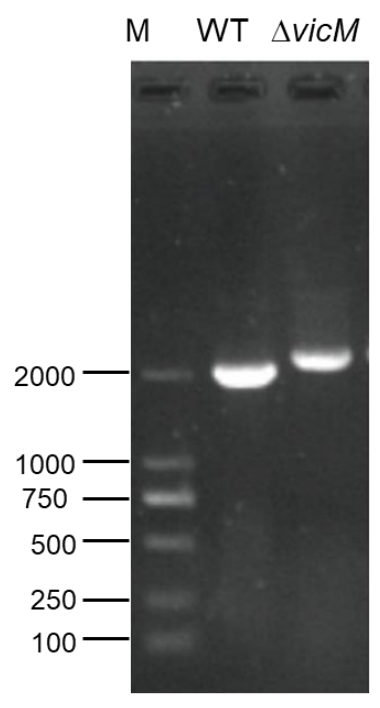

Figure S1. Disruption of vicM in wild-type S. parvus SCSIO Mla-L010 via PCRtargeting. (A) Schematic representation for disruption of vicM. (B) PCR analyses of the wild-type strain and the of vicM double-cross mutant carried out using the primers listed in Table S4. Marker: DNA molecular ladder; W: using the genomic DNA of $S$. parvus SCSIO Mla-L010 as template; $\triangle v i c M$ : using the genomic DNA of $\Delta v i c M$ mutant as template.

A

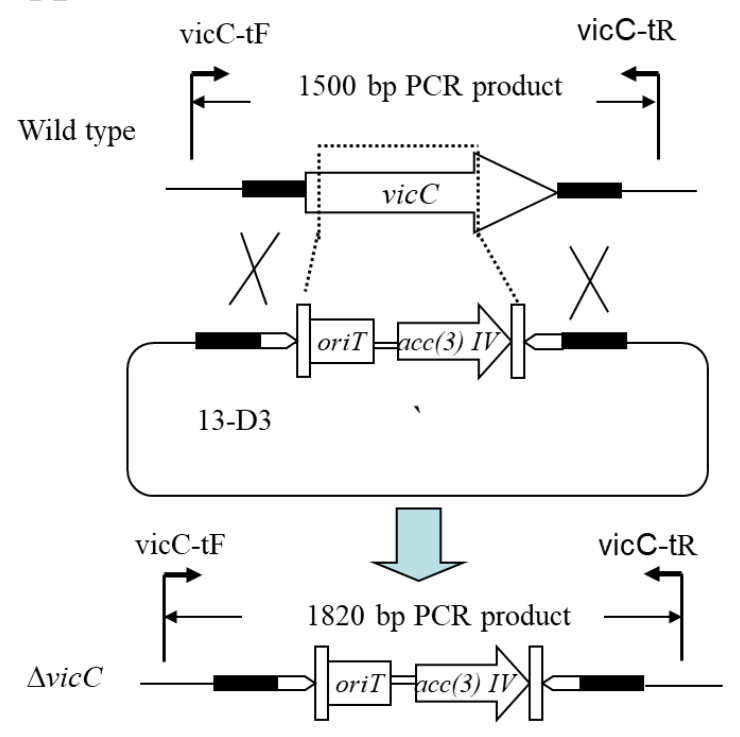

B

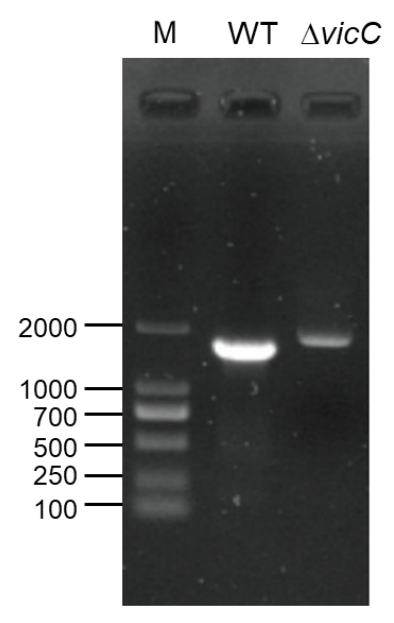

Figure S2. Disruption of vicC in wild-type S. parvus SCSIO Mla-L010 via PCRtargeting. (A) Schematic representation for disruption of vicC. (B) PCR analyses of the wild-type strain and the of vicM double-cross mutant carried out using the primers listed in Table S4. Marker: DNA molecular ladder; W: using the genomic DNA of $S$. parvus SCSIO Mla-L010 as template; $\triangle v i c C$ : using the genomic DNA of $\Delta v i c C$ mutant as template. 
A

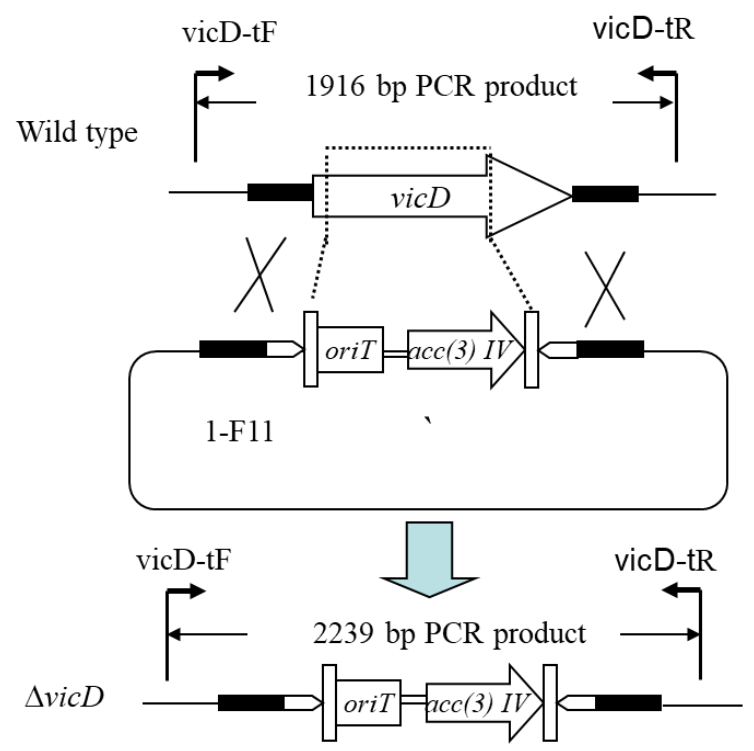

B

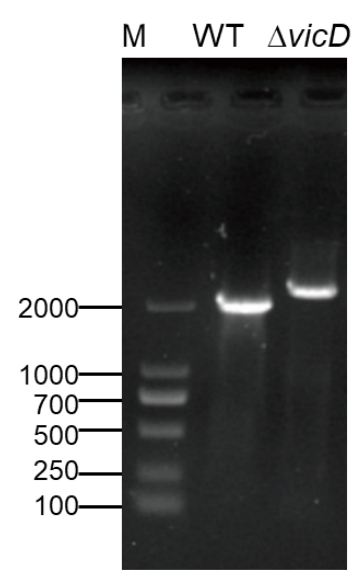

Figure S3. Disruption of vicD in wild-type S. parvus SCSIO Mla-L010 via PCRtargeting. (A) Schematic representation for disruption of vicD. (B) PCR analyses of the wild-type strain and the of vicD double-cross mutant carried out using the primers listed in Table S4. Marker: DNA molecular ladder; W: using the genomic DNA of S. parvus SCSIO Mla-L010 as template; $\Delta v i c D$ : using the genomic DNA of vicD mutant as template.

A

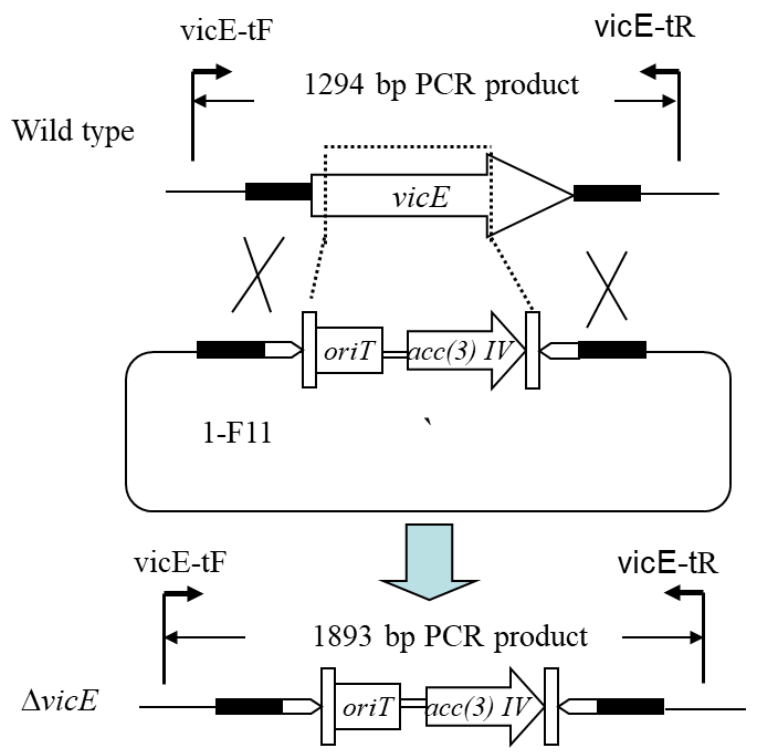

$\mathrm{B}$

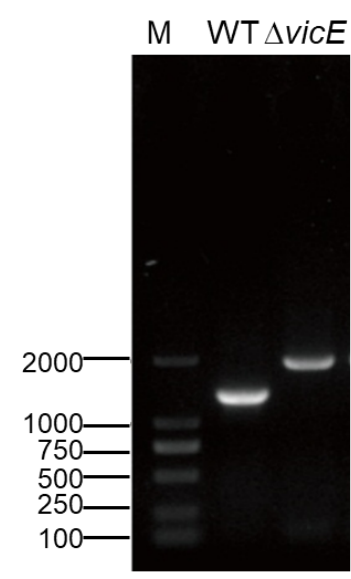

Figure S4. Disruption of vicE in wild-type S. parvus SCSIO Mla-L010 via PCRtargeting. (A) Schematic representation for disruption of vicE. (B) PCR analyses of the wild-type strain and the of vicE double-cross mutant carried out using the primers listed in Table S4. Marker: DNA molecular ladder; W: using the genomic DNA of $S$. 
parvus SCSIO Mla-L010 as template; $\Delta v i c E$ : using the genomic DNA of $\Delta v i c E$ mutant as template.

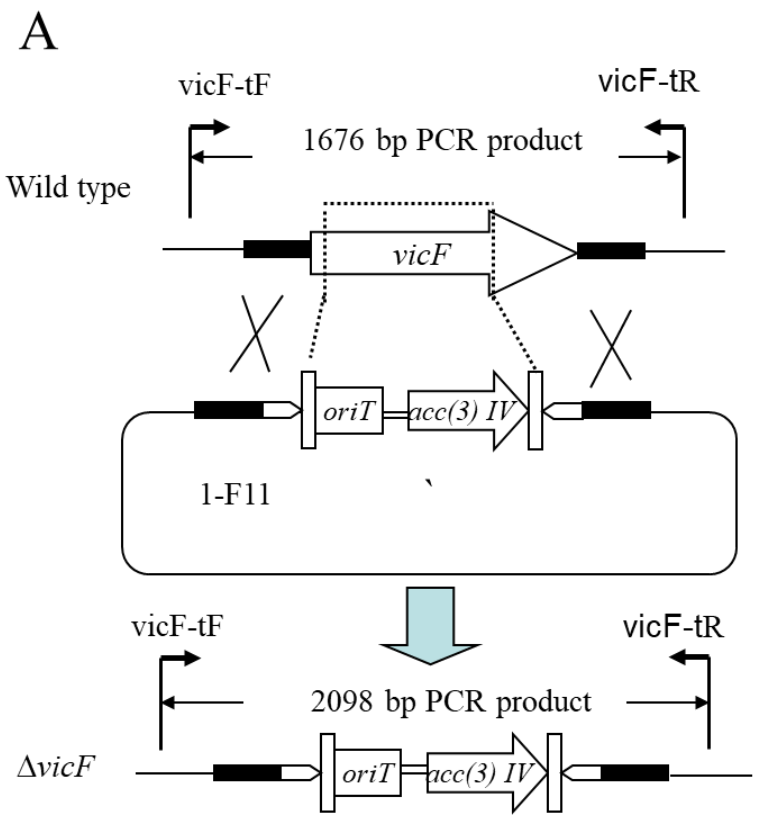

$\mathrm{B}$

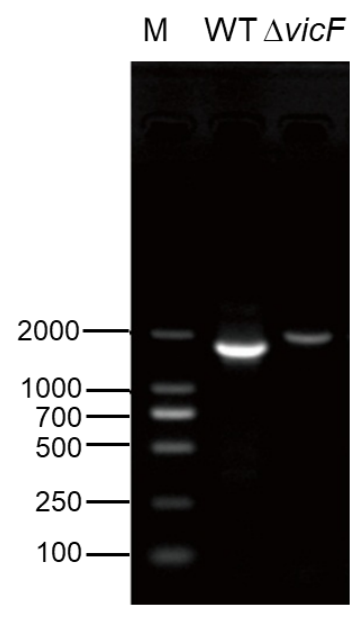

Figure S5. Disruption of vicF in wild-type S. parvus SCSIO Mla-L010 via PCRtargeting. (A) Schematic representation for disruption of vicF. (B) PCR analyses of the wild-type strain and the of vicF double-cross mutant carried out using the primers listed in Table S4. Marker: DNA molecular ladder; W: using the genomic DNA of $S$. parvus SCSIO Mla-L010 as template; $\Delta v i c F$ : using the genomic DNA of $\Delta v i c F$ mutant as template.

A

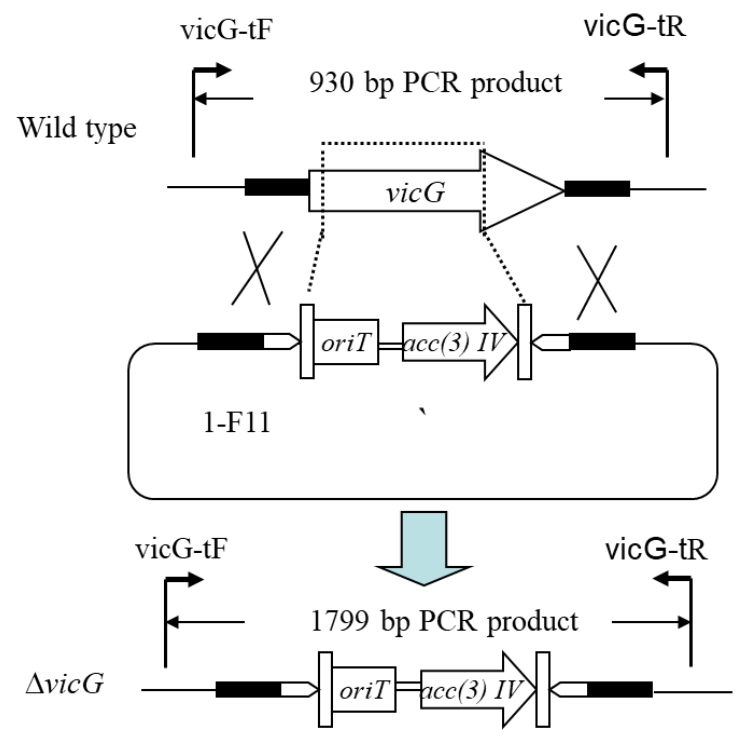

$\mathrm{B}$

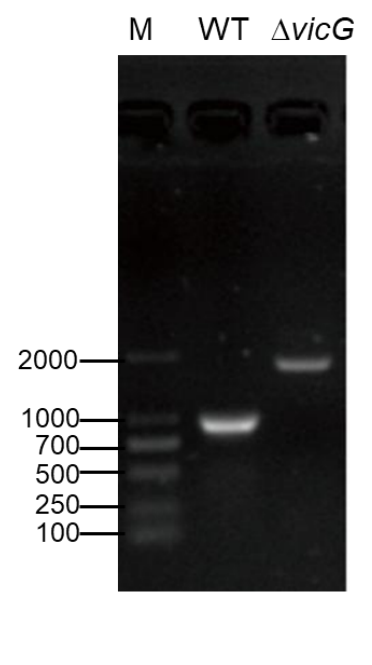

Figure S6. Disruption of vicG in wild-type S. parvus SCSIO Mla-L010 via PCRtargeting. (A) Schematic representation for disruption of vicG. (B) PCR analyses of the wild-type strain and the of vic $G$ double-cross mutant carried out using the primers 
listed in Table S4. Marker: DNA molecular ladder; W: using the genomic DNA of $S$. parvus SCSIO Mla-L010 as template; $\Delta v i c G$ : using the genomic DNA of $\Delta v i c G$ mutant as template.

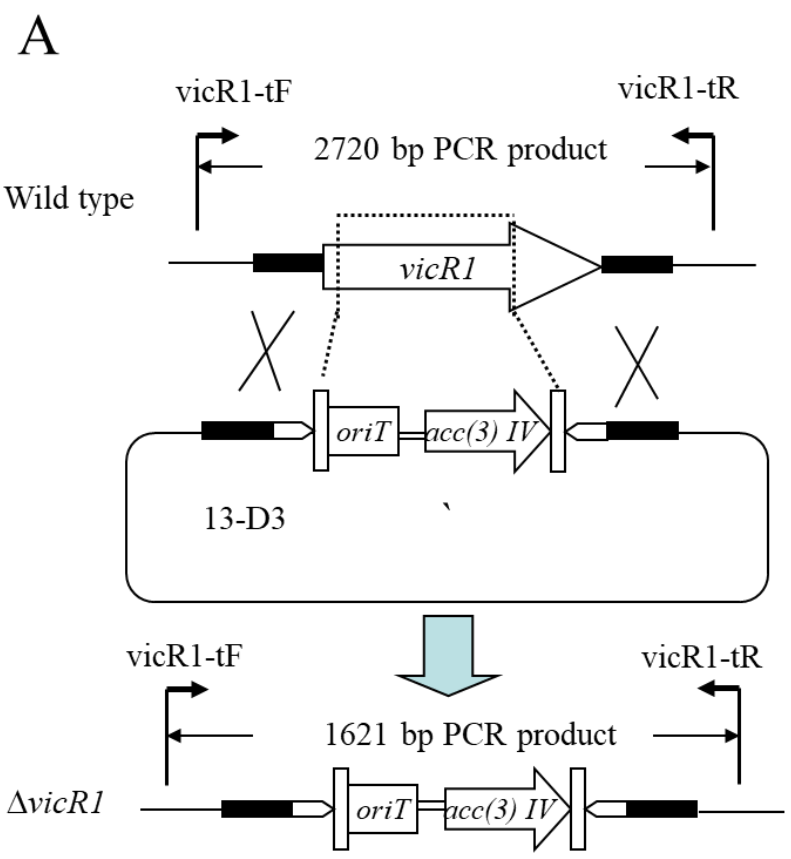

B

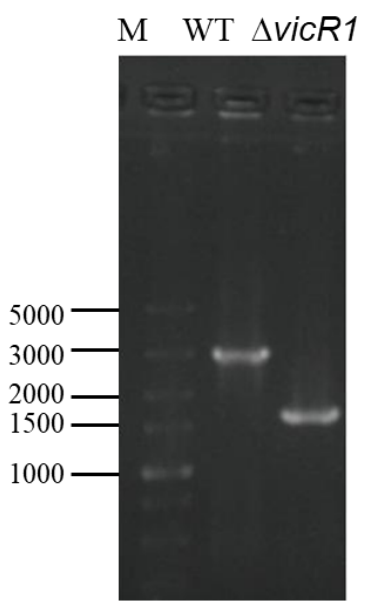

Figure S7. Disruption of vicRl in wild-type S. parvus SCSIO Mla-L010 via PCRtargeting. (A) Schematic representation for disruption of vicRl. (B) PCR analyses of the wild-type strain and the of vicRl double-cross mutant carried out using the primers listed in Table S4. Marker: DNA molecular ladder; W: using the genomic DNA of $S$. parvus SCSIO Mla-L010 as template; $\Delta v i c R 1$ : using the genomic DNA of $\Delta v i c R l$ mutant as template. 


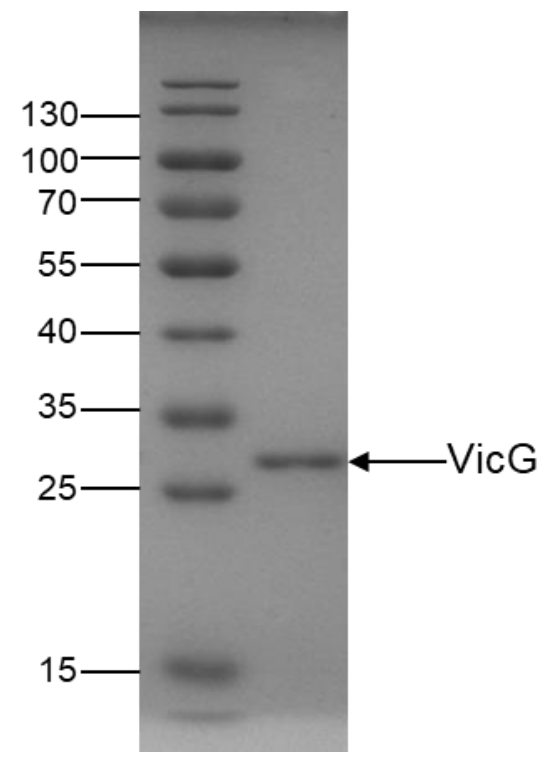

Figure S8. SDS-PAGE analysis of purified His $_{6}$-tagged VicG. 


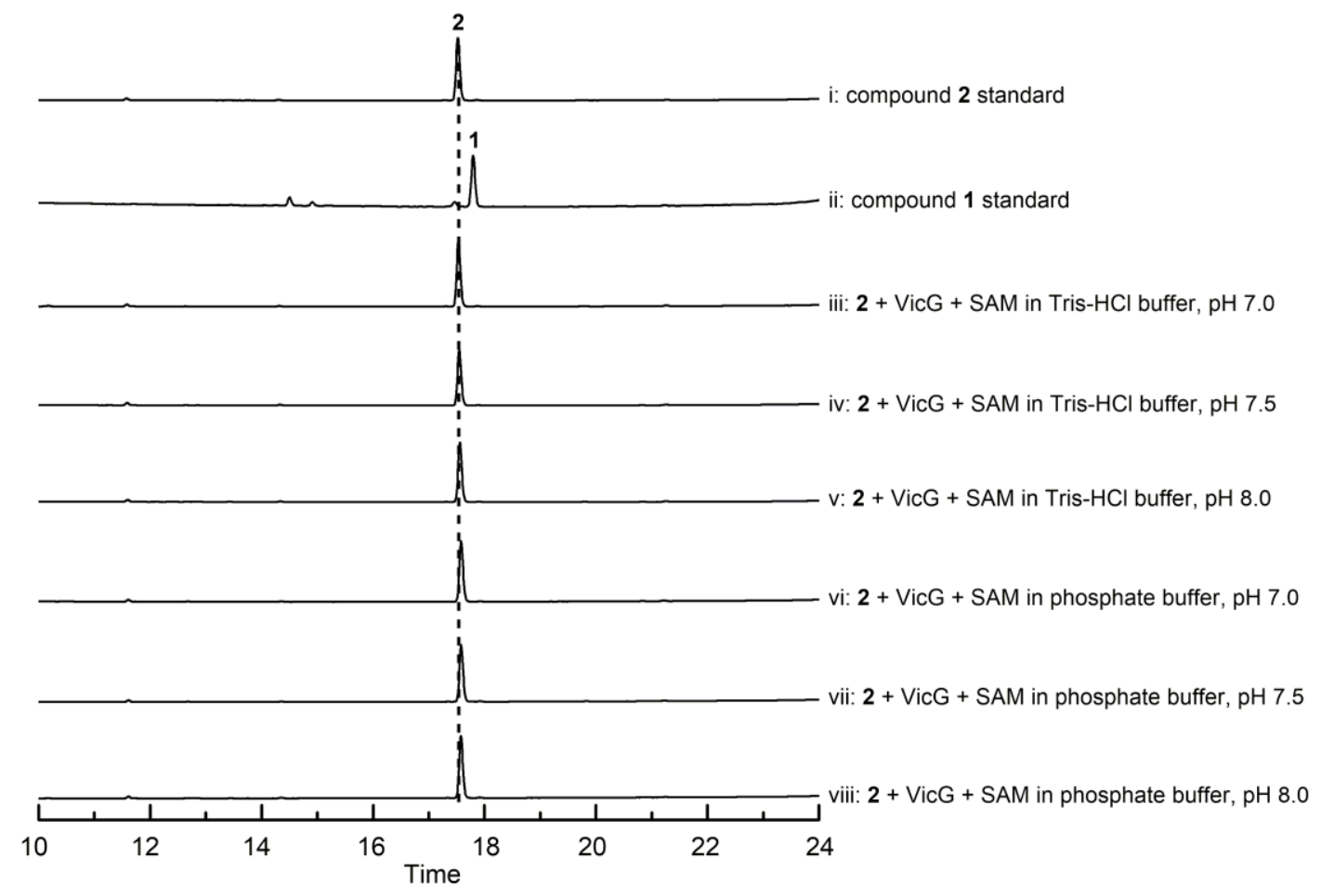

Figure S9. HPLC analyses of the enzymatic assays of VicG. 


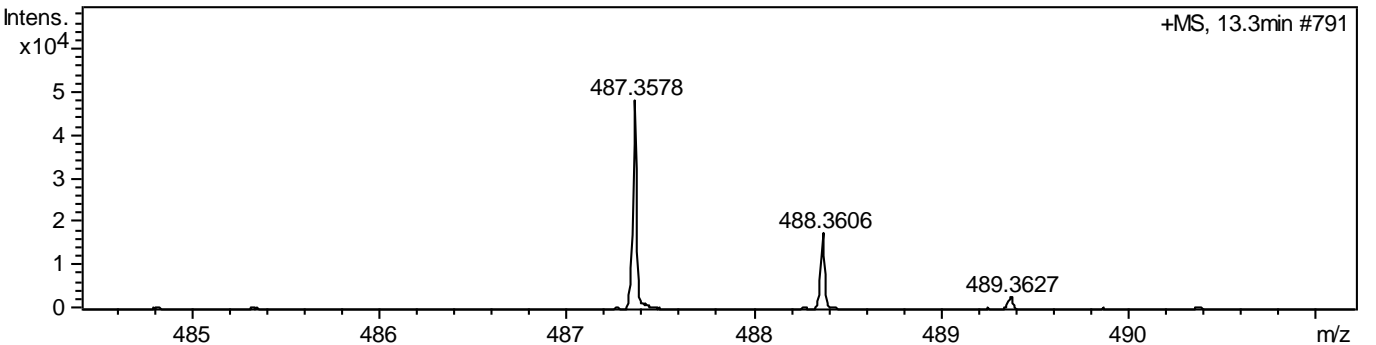

Figure S10. HR-ESI-MS spectrum of 2 from the LC-MS analysis of the fermentation extract of WT producer. The mass is consistent with the proposed structure of $\mathbf{2}$ with $\mathrm{m} / \mathrm{z}$ of $[\mathrm{M}+\mathrm{H}]^{+}=487.3578$ (calculated 487.3530). 


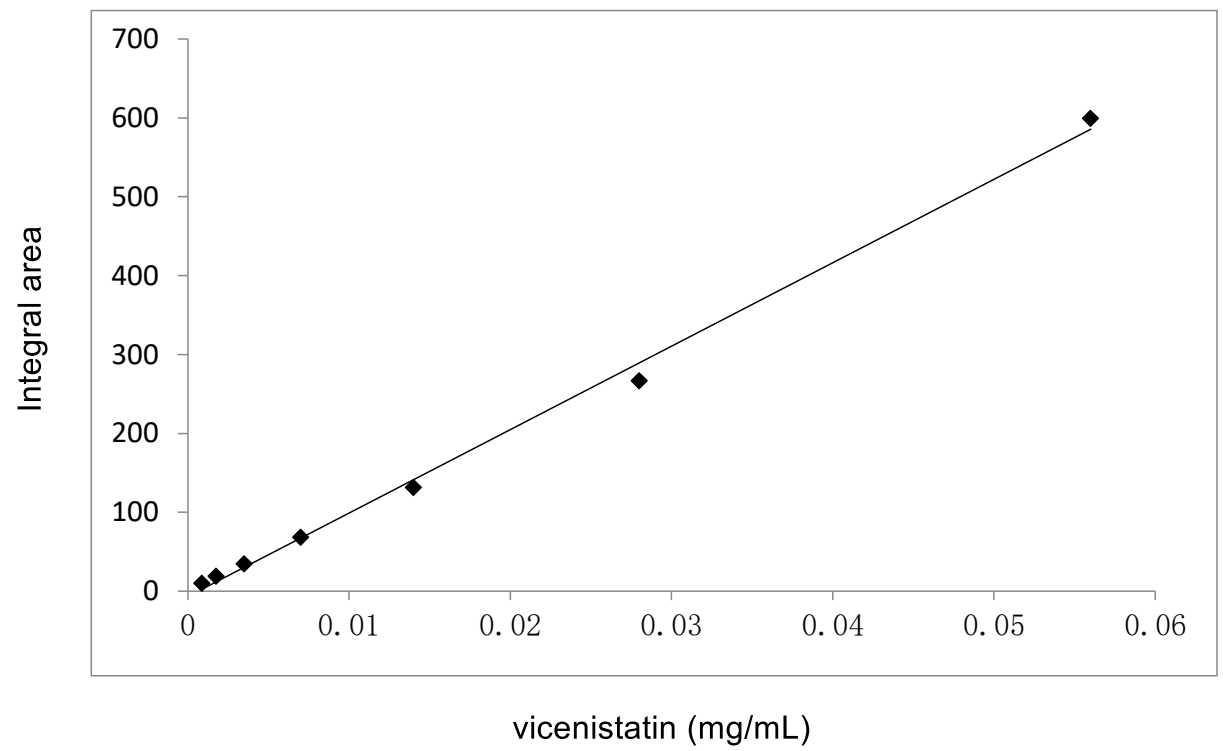

Figure S11. The quantitative HPLC standard curve for vicenistatin (1). The curve was generated via analysis of a concentration gradient of $0.0000875 \mathrm{mg} / \mathrm{mL}, 0.00175$ $\mathrm{mg} / \mathrm{mL}, 0.0035 \mathrm{mg} / \mathrm{mL}, 0.007 \mathrm{mg} / \mathrm{mL}, 0.014 \mathrm{mg} / \mathrm{mL}, 0.028 \mathrm{mg} / \mathrm{mL}, 0.056 \mathrm{mg} / \mathrm{mL}$ of 1. UV absorptions were maintained below $1 \mathrm{~A}$ unit to ensure appropriate confidence of the generated standard curve and avoid deviation from linearity.

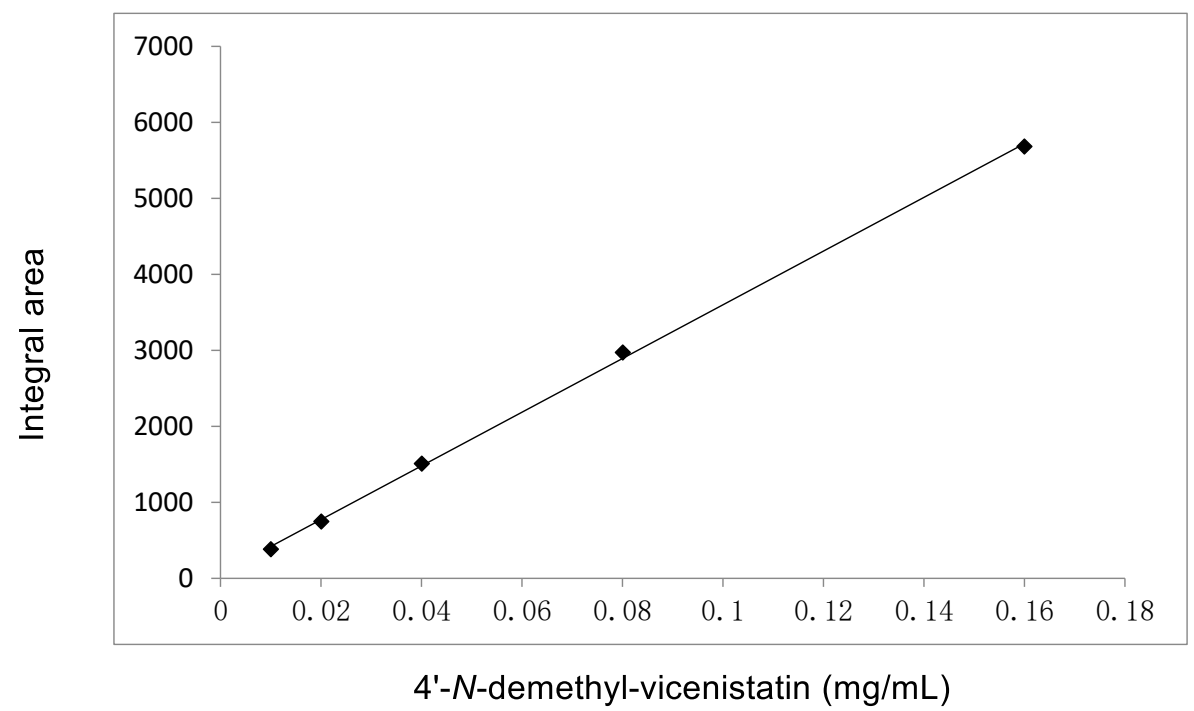

Figure S12. The quantitative HPLC standard curve for 4'- $N$-demethyl-vicenistatin (2). The curve was generated via analysis of a concentration gradient of $0.01 \mathrm{mg} / \mathrm{mL}, 0.02$ $\mathrm{mg} / \mathrm{mL}, 0.04 \mathrm{mg} / \mathrm{mL}, 0.08 \mathrm{mg} / \mathrm{mL}, 0.16 \mathrm{mg} / \mathrm{mL}$ of 2 . UV absorptions were maintained below $1 \mathrm{~A}$ unit to ensure appropriate confidence of the generated standard curve and avoid deviation from linearity. 
Figure S13. The (+) HRESIMS spectrum of 1.

1

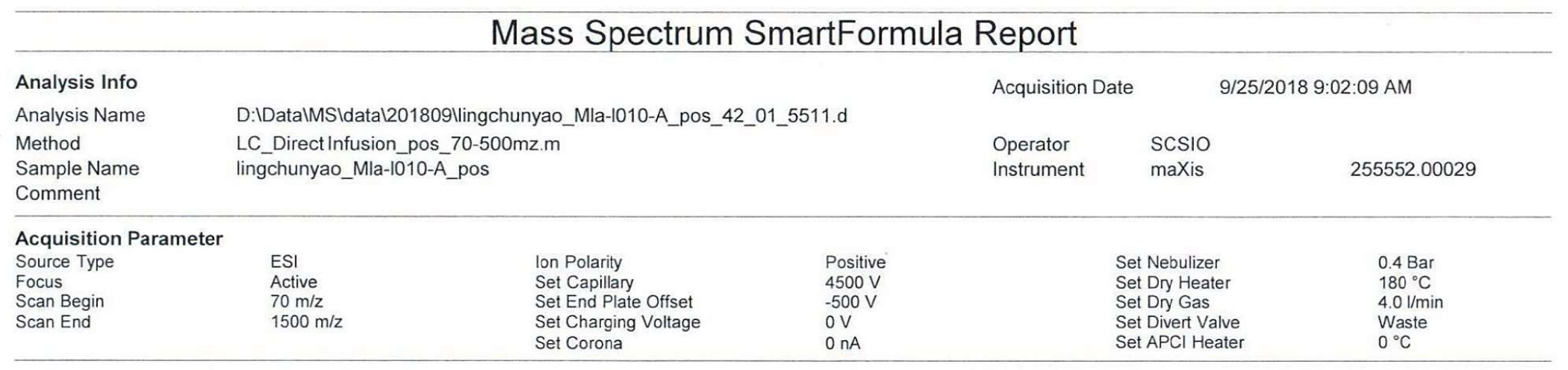

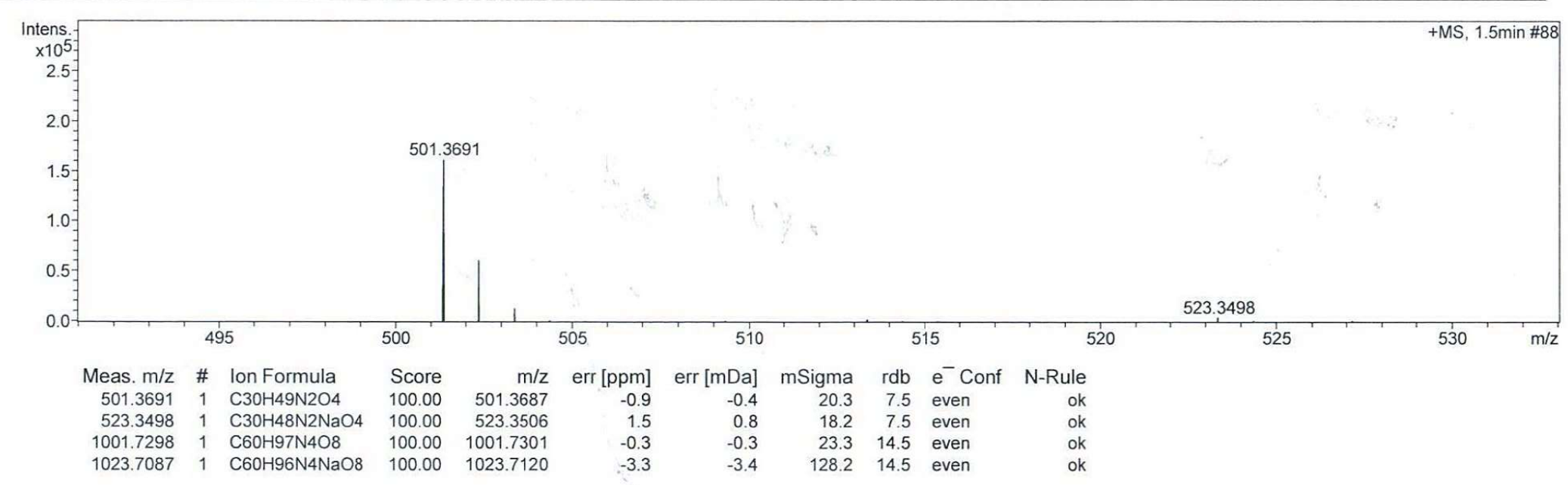


Figure S14. ${ }^{1} \mathrm{H}$ NMR $(700 \mathrm{MHz})$ spectrum of 1 in pyridine- $d_{5}$.

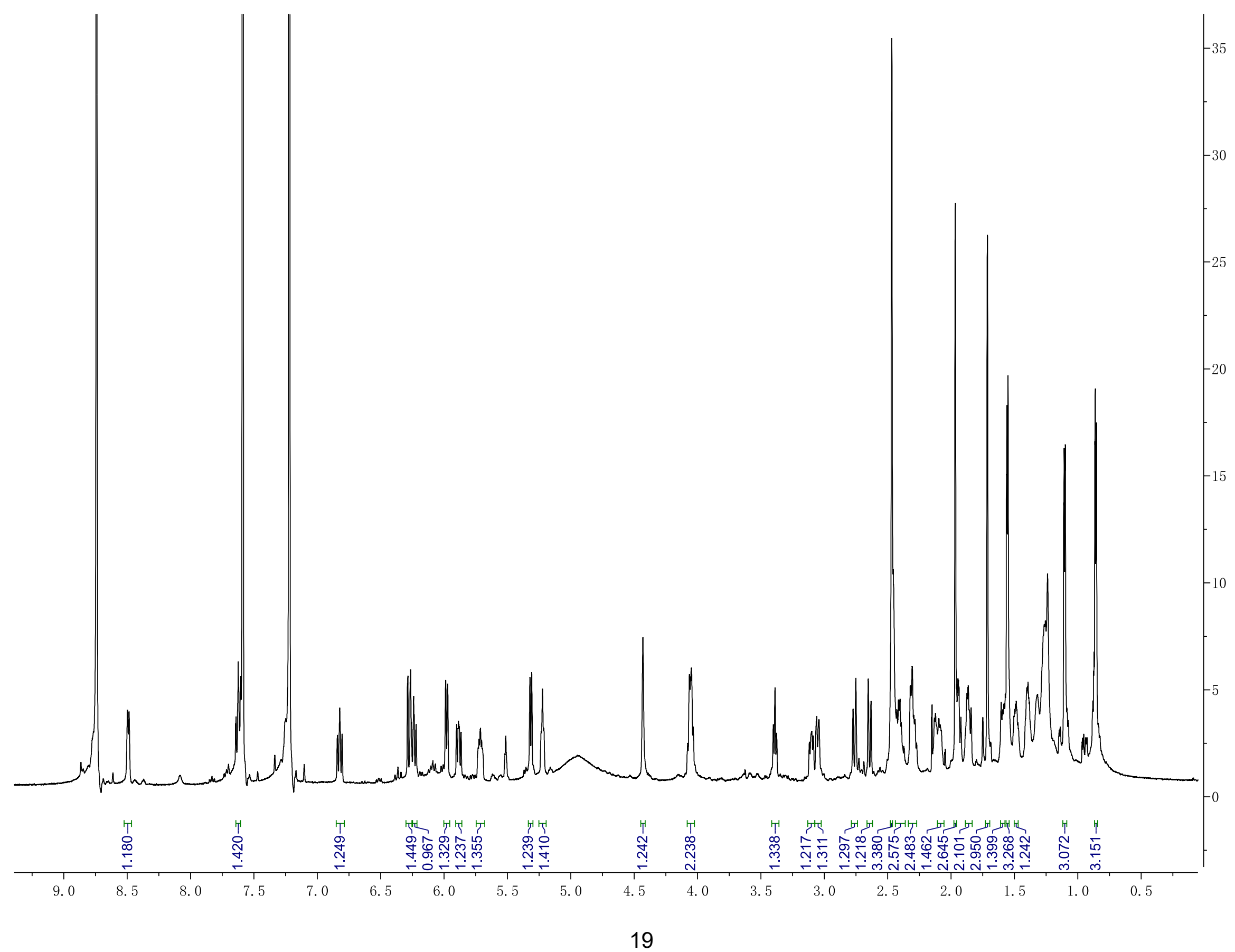


Figure S15. ${ }^{13} \mathrm{C}$ NMR (176 MHz) spectrum of 1 in pyridine- $d_{5}$.

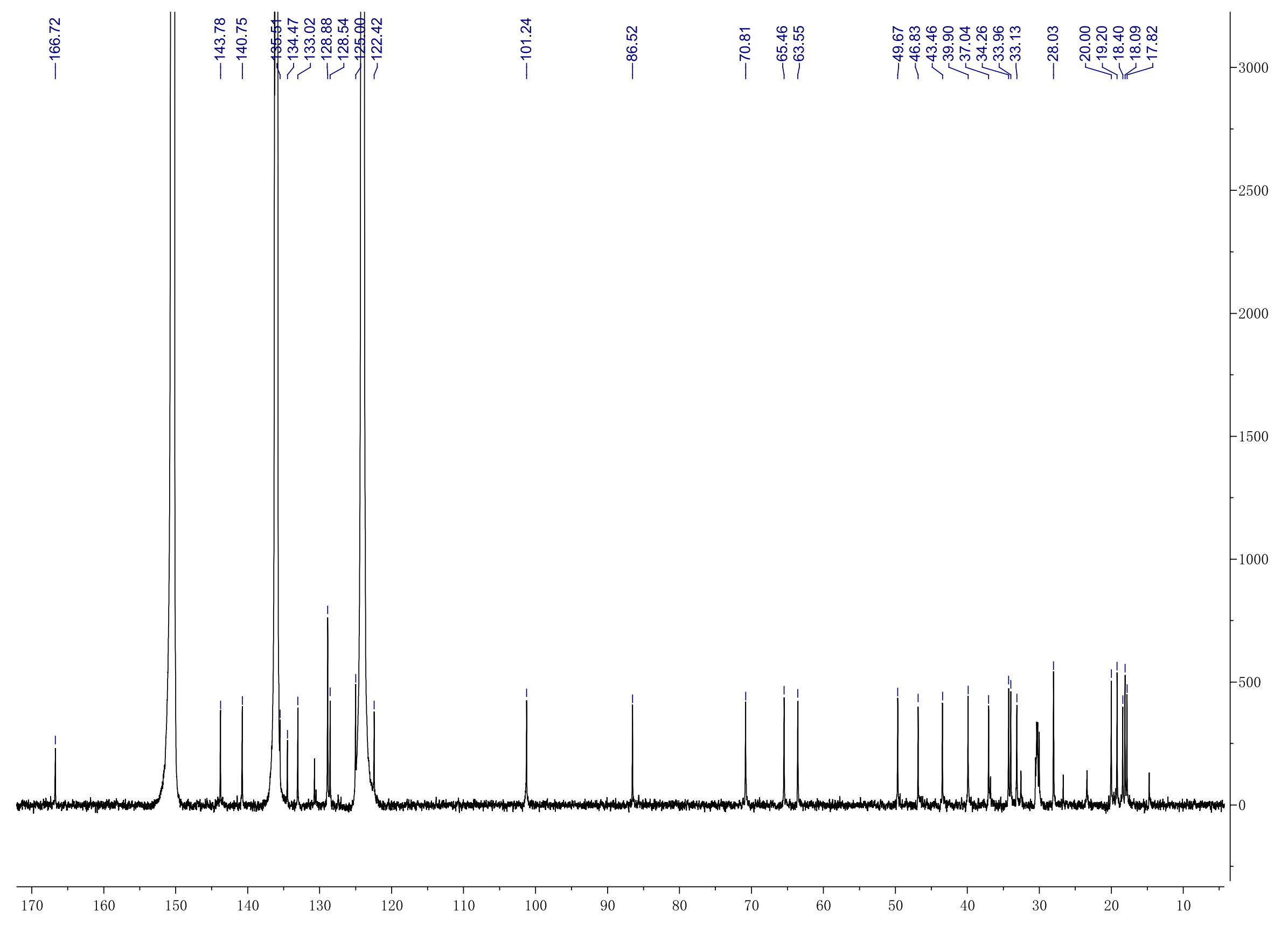


Figure S16. COSY spectrum of 1 in pyridine- $d_{5}$.

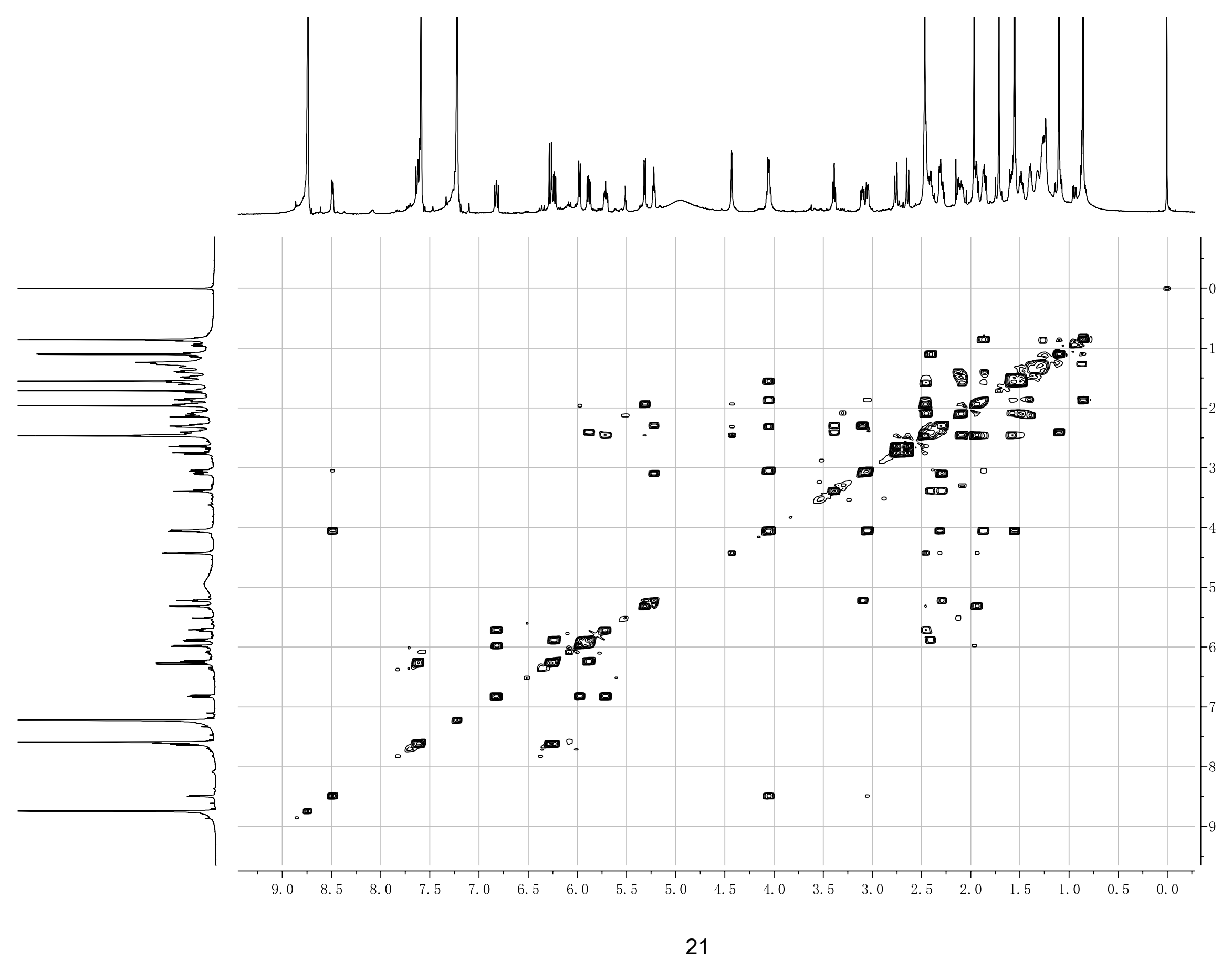


Figure S17. NOESY spectrum of 1 in pyridine- $d_{5}$.

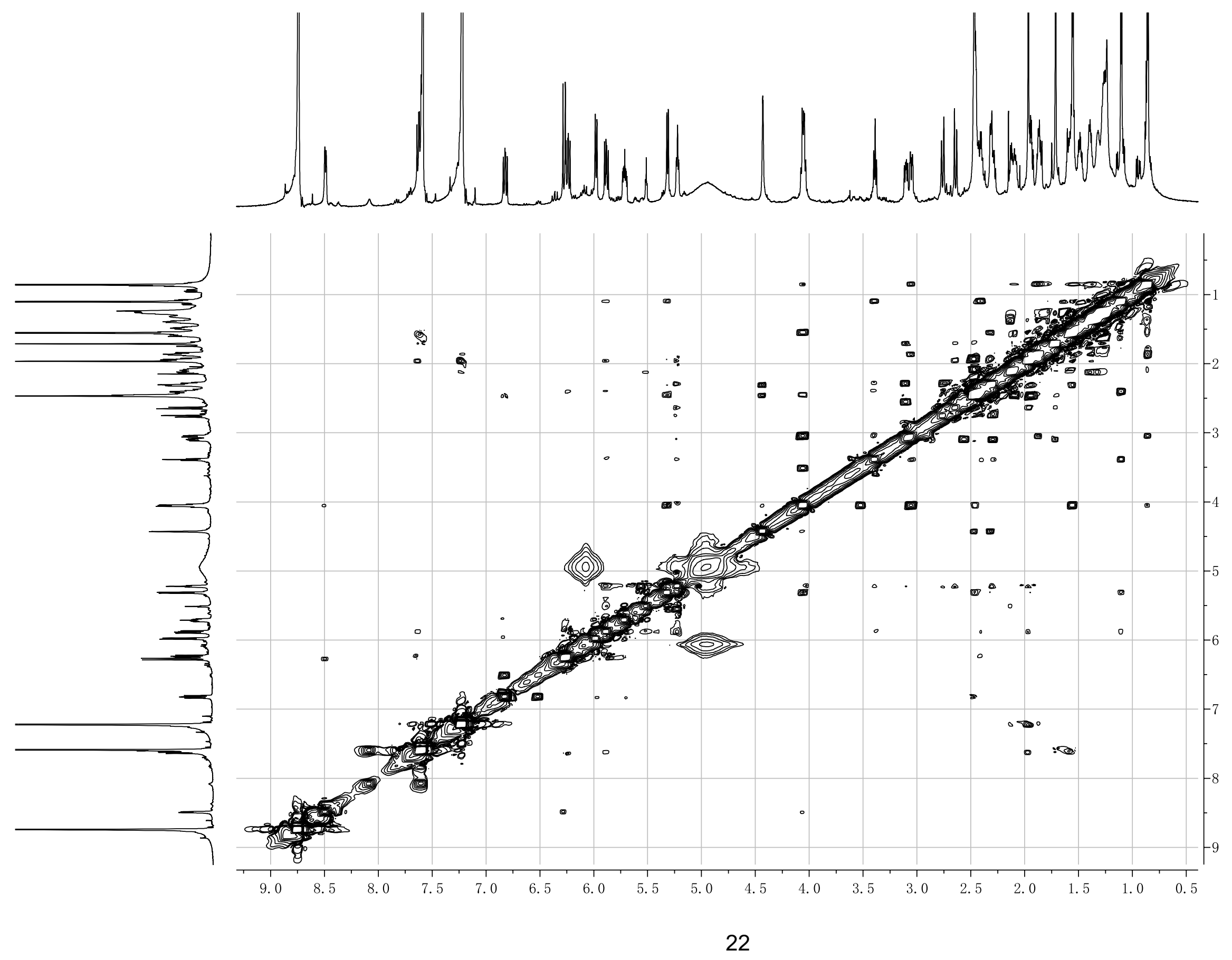


Figure S18. HSQC spectrum of 1 in pyridine- $d_{5}$.

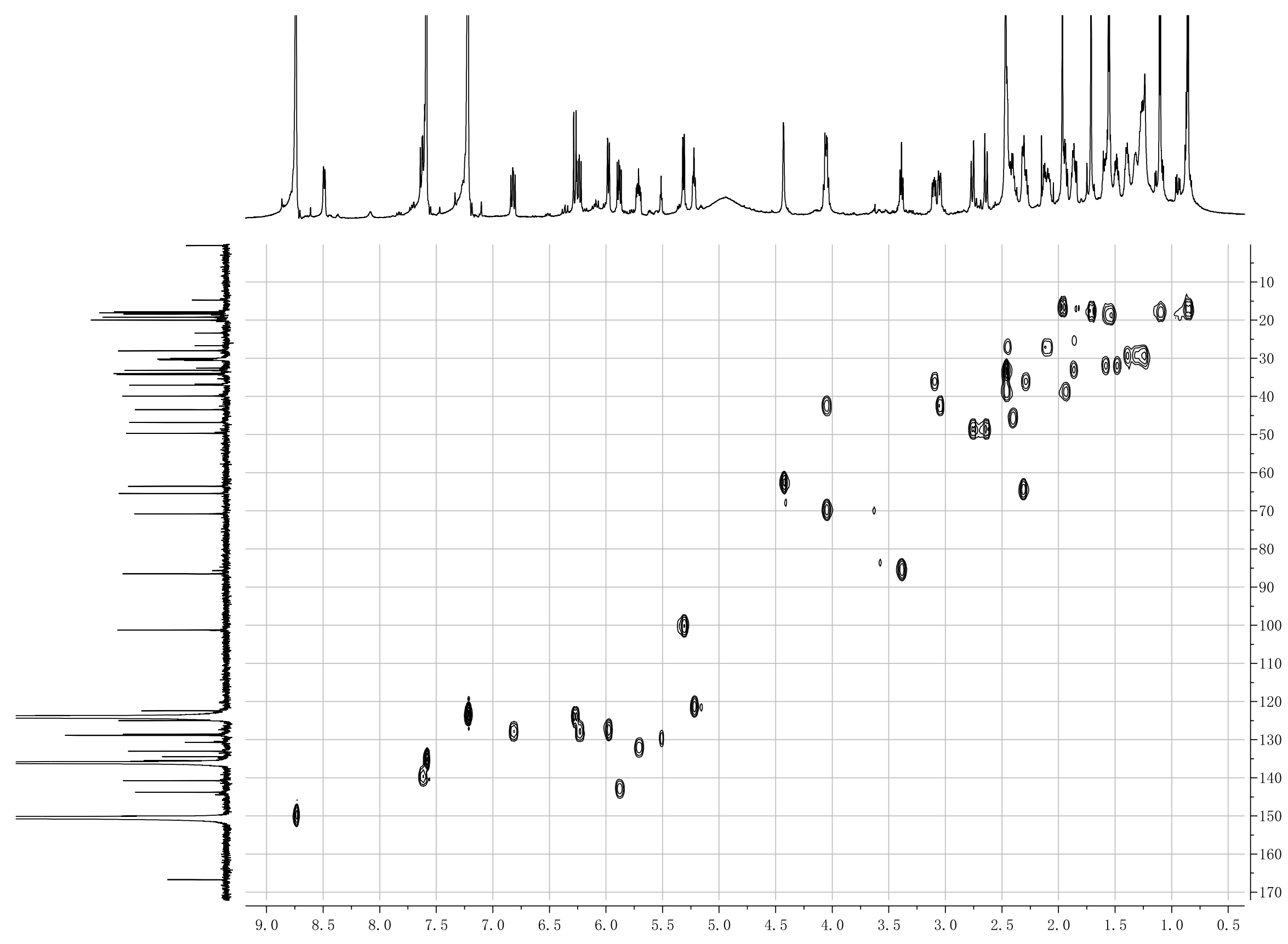


Figure S19. HMBC spectrum of 1 in pyridine- $d_{5}$.

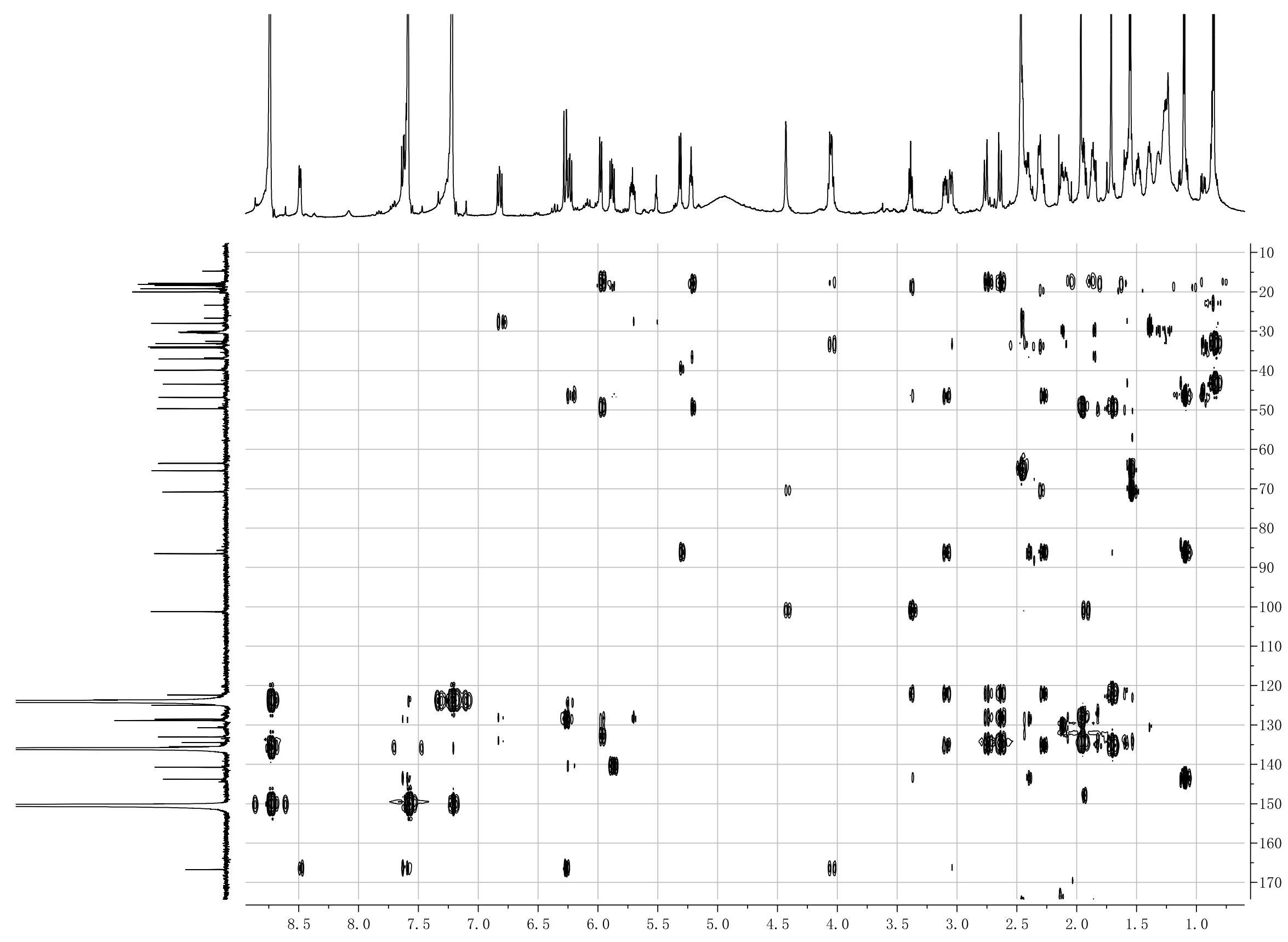


Figure S20. the (+) HRESIMS spectrum of 2.

\begin{tabular}{|c|c|c|c|c|c|c|}
\hline \multicolumn{7}{|c|}{ Mass Spectrum SmartFormula Report } \\
\hline Analysis Info & & & & Acquisition & \multicolumn{2}{|c|}{ 1/27/2021 5:36:01 PM } \\
\hline Analysis Name & \multicolumn{3}{|c|}{ D:IDatalMSIdatal202101Vliangzhicheng_G-A_pos_22_01_9878.d } & & & \\
\hline $\begin{array}{l}\text { Method } \\
\text { Sample Name } \\
\text { Comment }\end{array}$ & \multicolumn{3}{|c|}{$\begin{array}{l}\text { LC_Direct Infusion_pos_70-500mz.m } \\
\text { liangzhicheng_G-A_pos }\end{array}$} & $\begin{array}{l}\text { Operator } \\
\text { Instrument }\end{array}$ & $\begin{array}{l}\text { SCSIO } \\
\text { maXis }\end{array}$ & 255552.00029 \\
\hline \multicolumn{7}{|c|}{ Acquisition Parameter } \\
\hline $\begin{array}{l}\text { Source Type } \\
\text { Focus } \\
\text { Scan Begin } \\
\text { Scan End }\end{array}$ & $\begin{array}{l}\text { ESI } \\
\text { Active. } \\
70 \mathrm{~m} / \mathrm{z} \\
1500 \mathrm{~m} / \mathrm{z}\end{array}$ & $\begin{array}{l}\text { Ion Polarity } \\
\text { Set Capillary } \\
\text { Set End Plate Offset } \\
\text { Set Charging Voltage } \\
\text { Set Corona }\end{array}$ & $\begin{array}{l}\text { Positive } \\
4500 \mathrm{~V} \\
-500 \mathrm{~V} \\
0 \mathrm{~V} \\
0 \mathrm{nA}\end{array}$ & & $\begin{array}{l}\text { Set Nebulizer } \\
\text { Set Dry Heater } \\
\text { Set Dry Gas } \\
\text { Set Divert Valve } \\
\text { Set APCl Heater }\end{array}$ & $\begin{array}{l}0.4 \mathrm{Bar} \\
180^{\circ} \mathrm{C} \\
4.0 \mathrm{l} / \mathrm{min} \\
\text { Waste } \\
0^{\circ} \mathrm{C}\end{array}$ \\
\hline
\end{tabular}

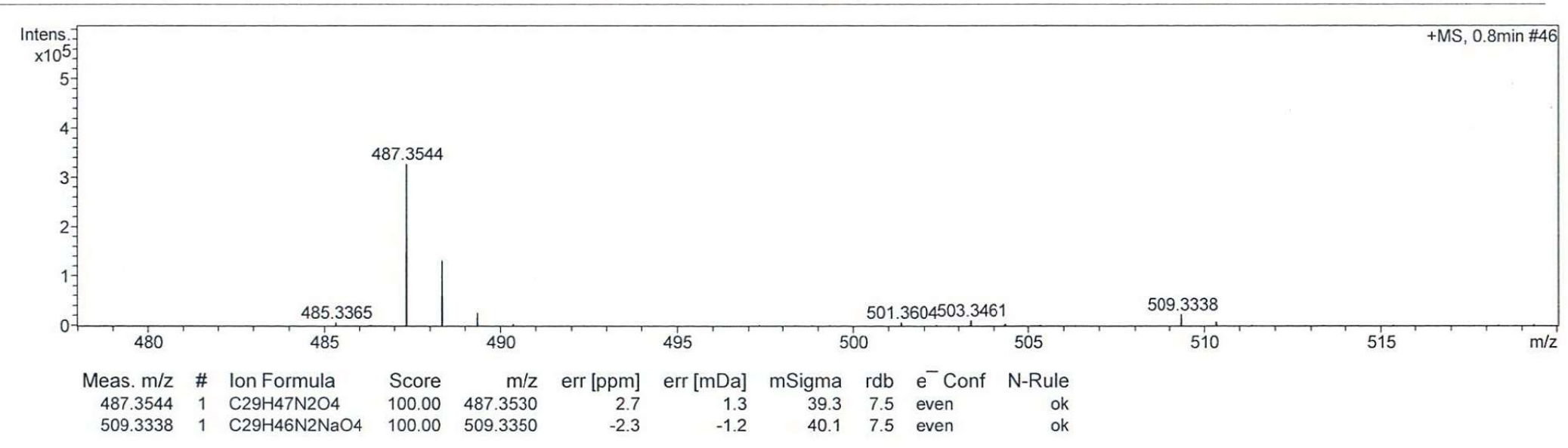

liangzhicheng_G-A pos_22_01_9878.d 
Figure S21. ${ }^{1} \mathrm{H}$ NMR $(700 \mathrm{MHz})$ spectrum of 2 in pyridine- $d_{5}$.

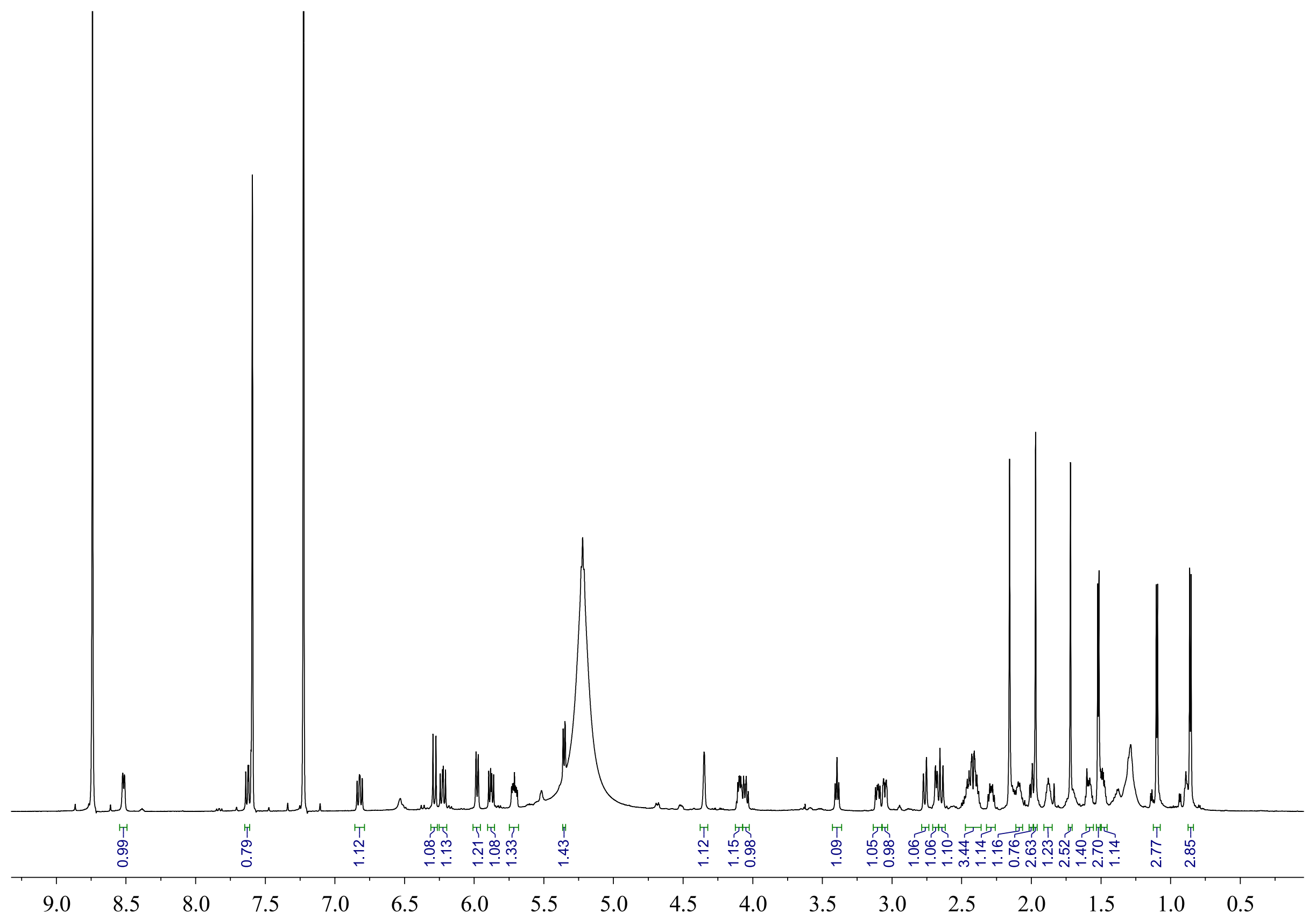


Figure S22. ${ }^{13} \mathrm{C}$ NMR $(176 \mathrm{MHz})$ spectrum of 2 in pyridine- $d_{5}$.

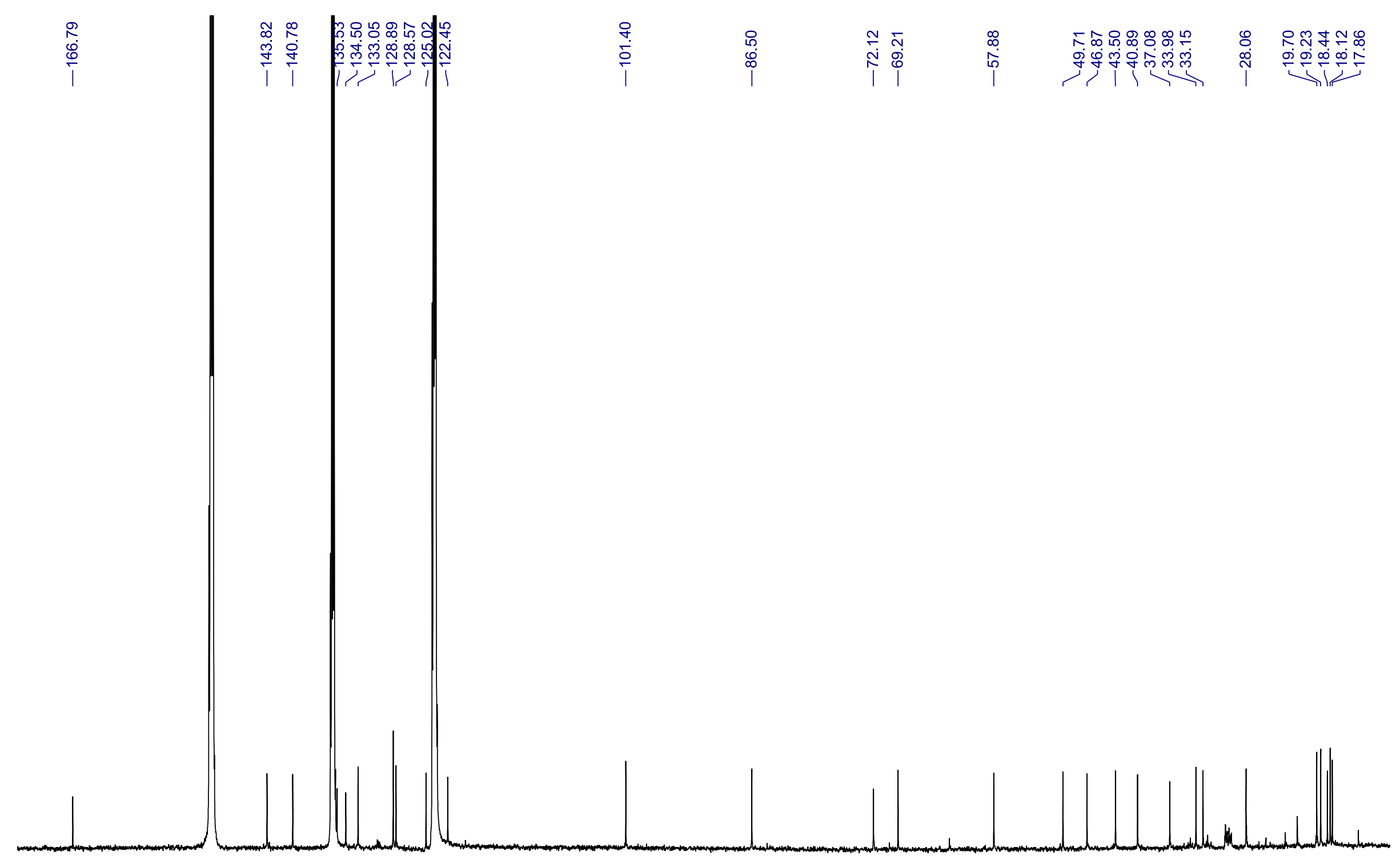

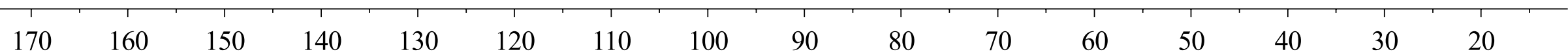


Figure S23. COSY spectrum of 2 in pyridine- $d_{5}$.

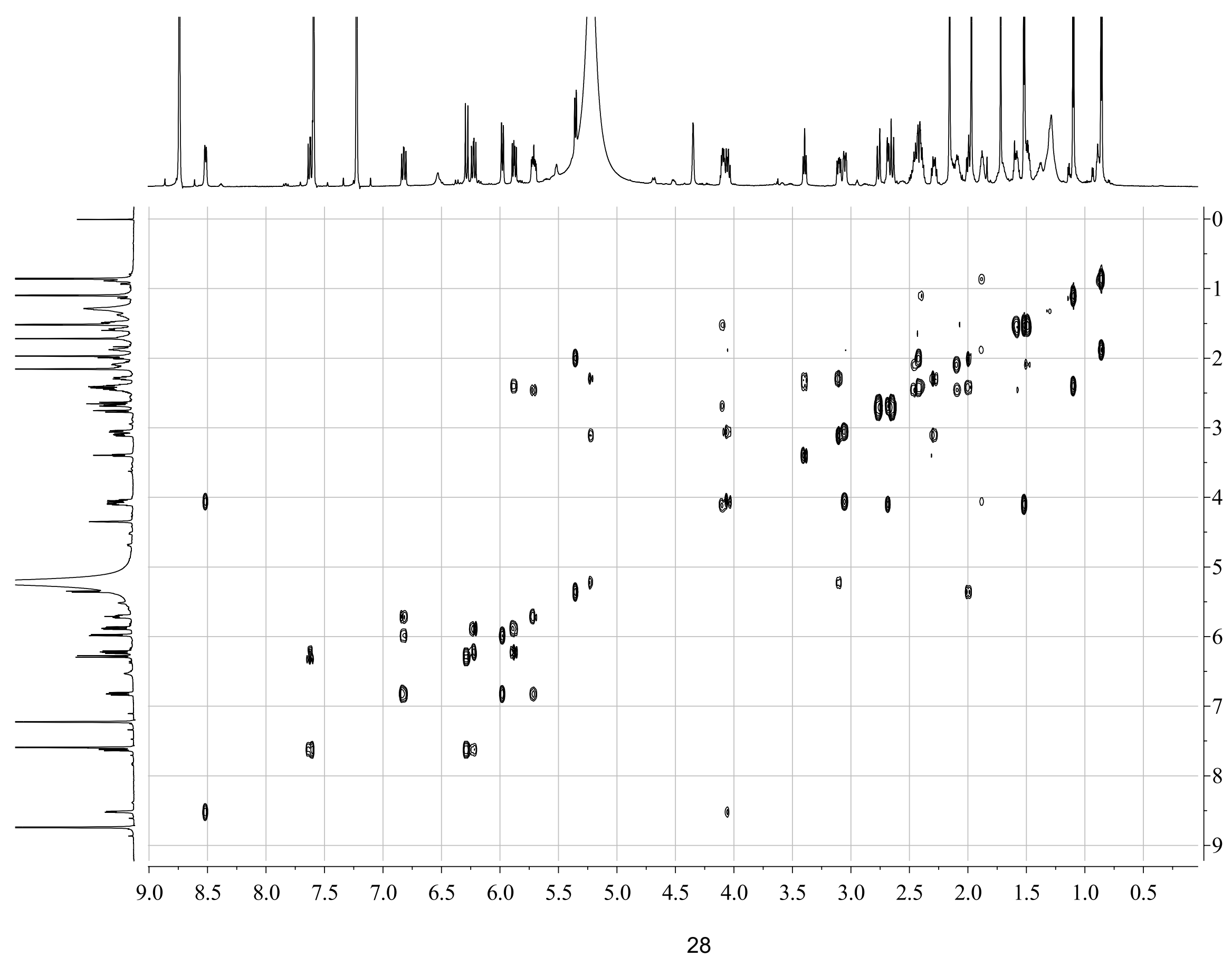


Figure S24. NOESY spectrum of 2 in pyridine- $d_{5}$.

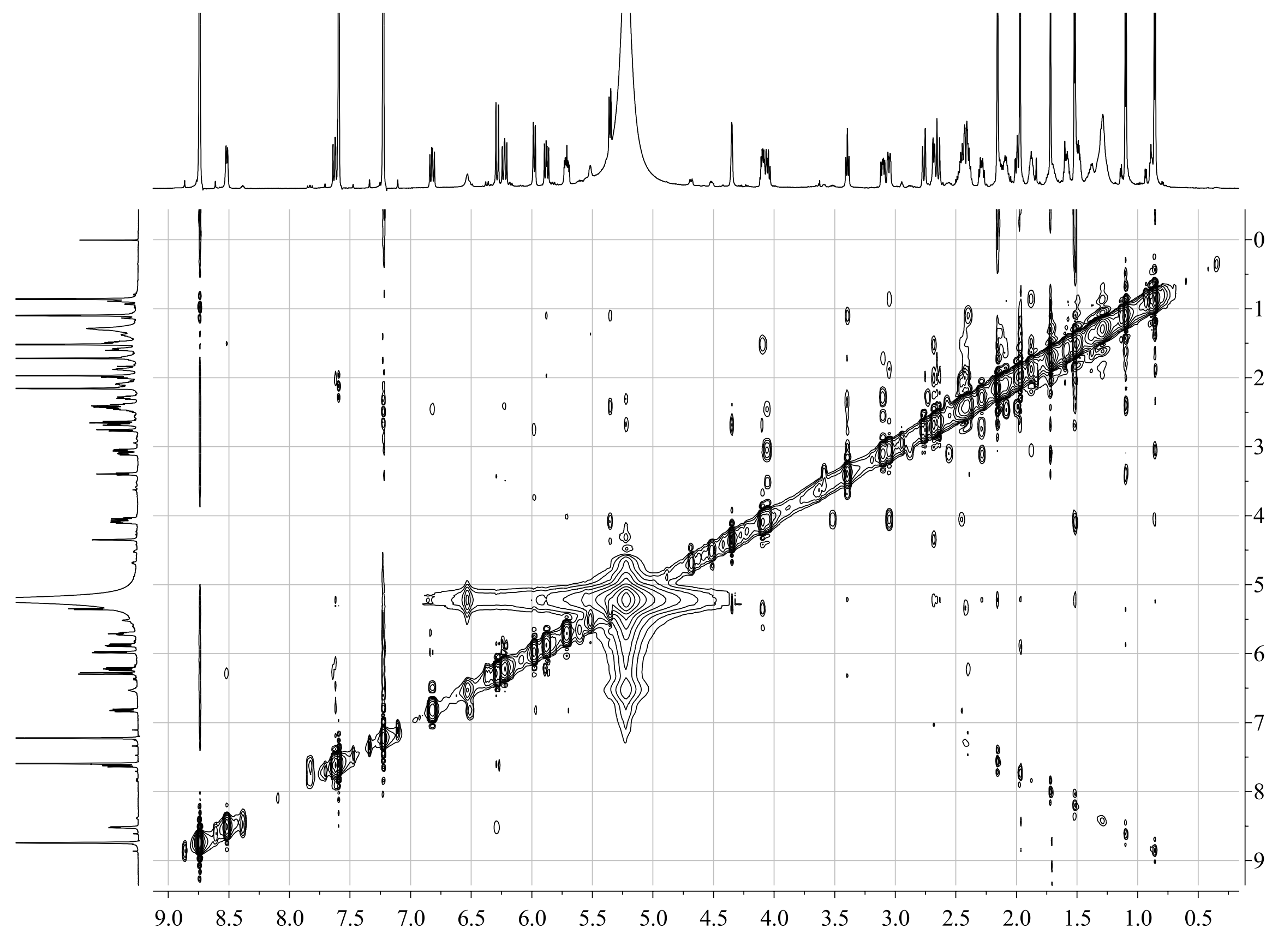


Figure S25. HSQC spectrum of 2 in pyridine- $d_{5}$.

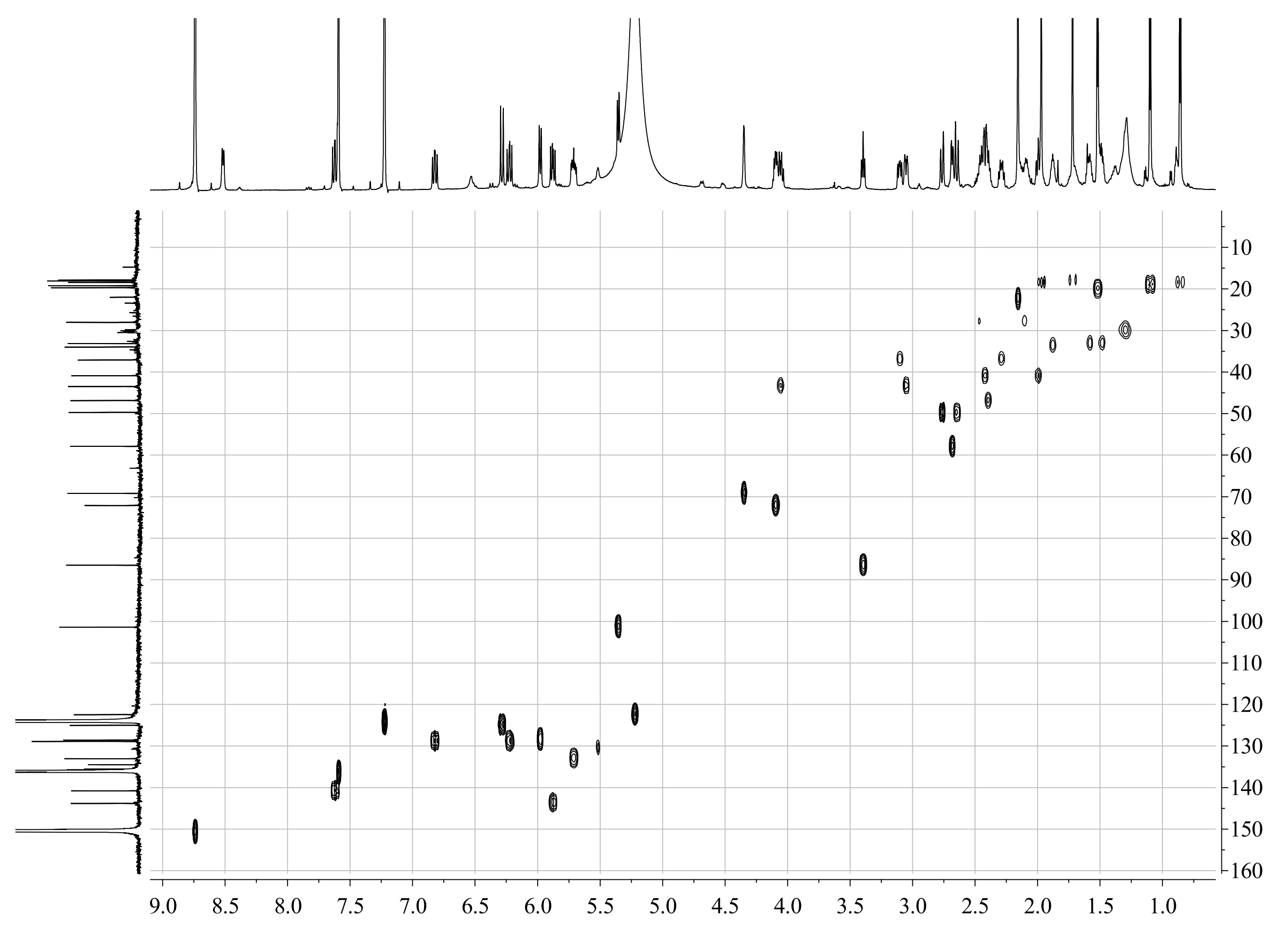


Figure S26. HMBC spectrum of 2 in pyridine- $d_{5}$.

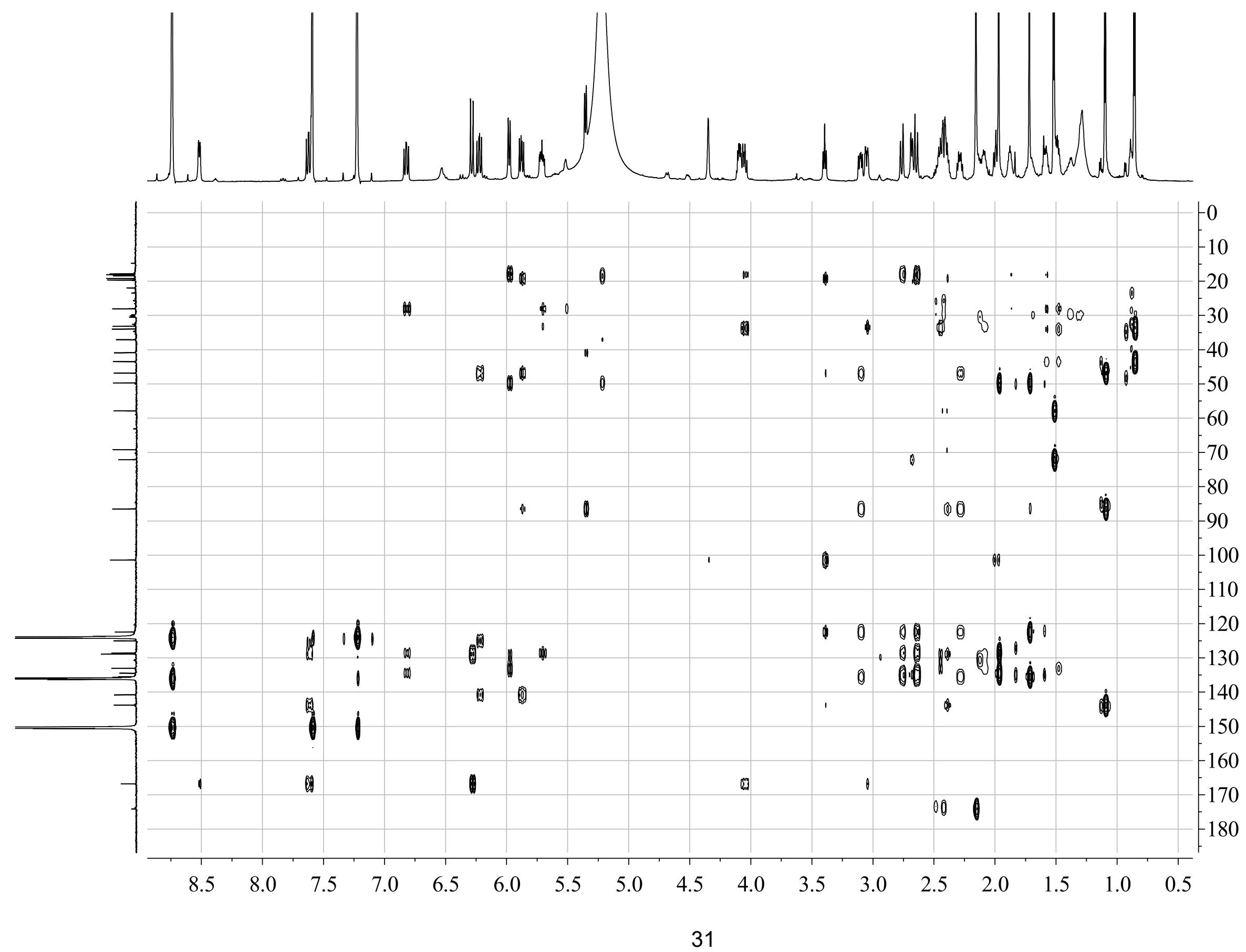




\section{REFERENCES}

[1]. Datsenko, K. A.; Wanner, B. L. Proc. Natl. Acad. Sci. U. S. A. 2000, 97, 66406645.

[2]. MacNeil, D. J.; Gewain, K. M.; Ruby, C. L.; Dezeny, G.; Gibbons, P. H.; MacNeil, T. Gene 1992, 111, 61-68.

[3]. Gust, B.; Challis, G. L.; Fowler, K.; Kieser, T.; Chater, K. F. Proc. Natl. Acad. Sci. U. S. A. 2003, 100, 1541-1546.

[4]. Hong, B.; Phornphisutthimas, S.; Tilley, E.; Baumberg, S.; McDowall, K. J. Biotechnol. Lett. 2007, 29, 57-64. 